POWANSS NATURE WOKS, NO:5 GPNEZ. Toadstools

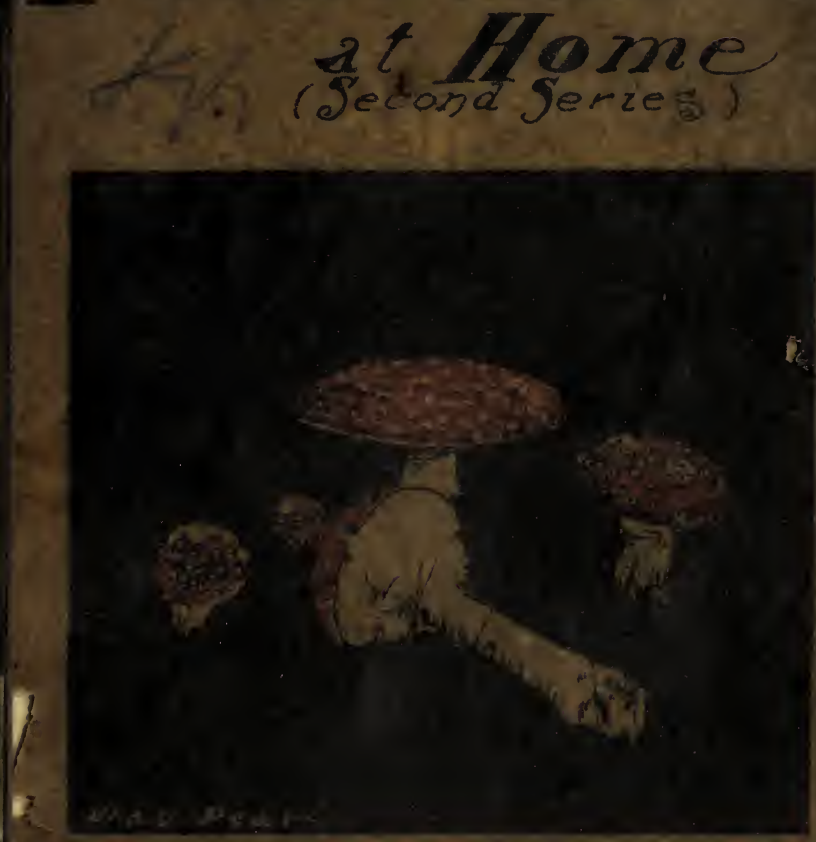
1.

3 Somenville Hastunga. Fi. S S Loncion है GidsGon: Gowang \& Gray. $\backslash<t d$. 


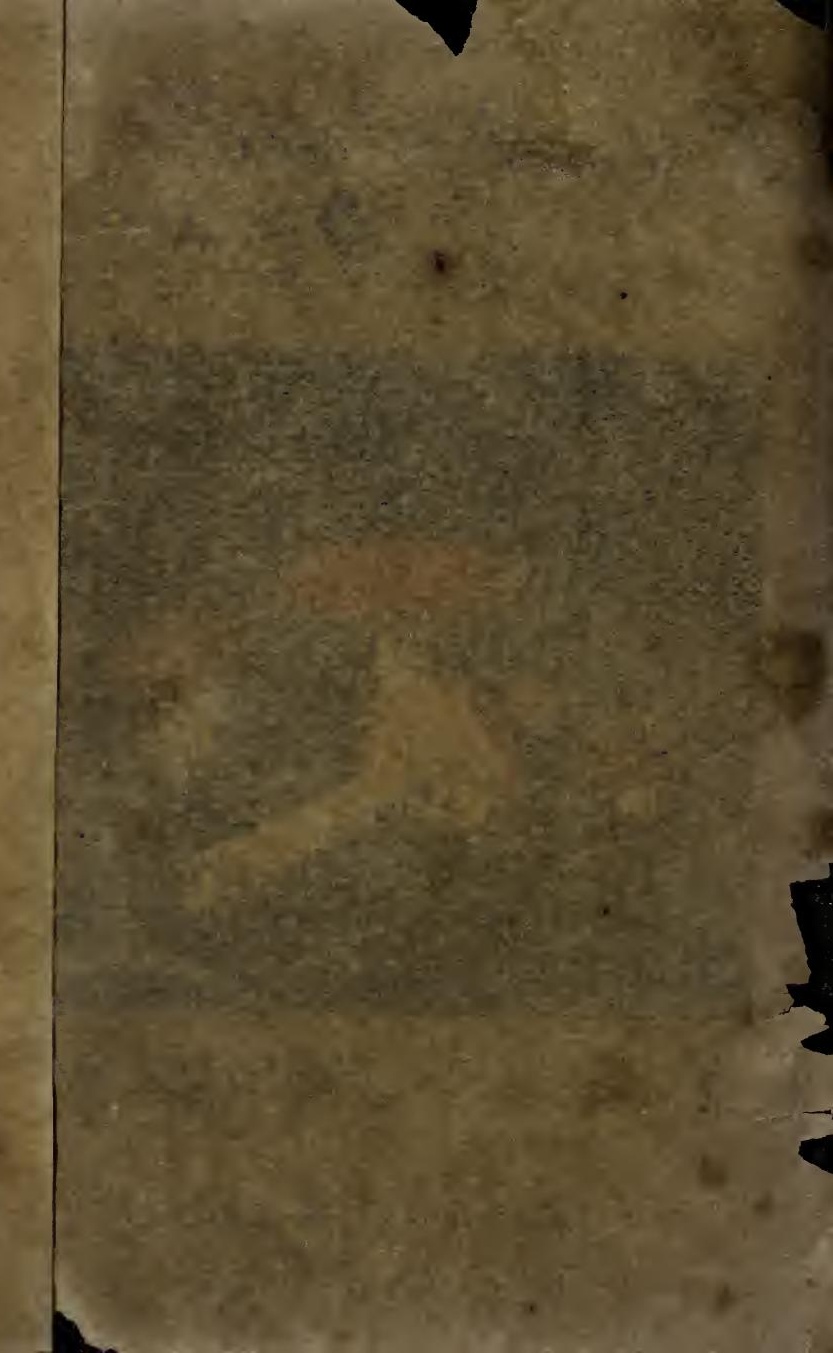





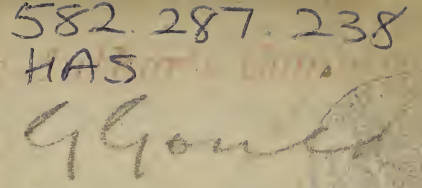

\section{Gowans's Nature Books}

THE object of these little books is to stimulate a love for nature and a desire to study it.

All the volumes of the series that have been issued so far have been very successful, and the publishers hope to be able to maintain the very high standard of excellence which has made this series so well known all over the country. Some of the photographs included in the different volumes are unequalled and unique triumphs of the naturephotographer's art.

No. r.-WILD BIRDS AT HOME. Sixty Photo. graphs from Life, by Chas. Kirk, of British Birds and their Nests.

No. 2.-WILD FLOWERS AT HOME. First Series. Sixty Photographs from Nature, by Cameron Todd.

No. 3.-WILD FLOWERS AT HOME. Second Series. By the Same.

No. 4.-BUTTERFLIES AND MOTHS AT HOME. Sixty Photographs from Life, by A. Forrester.

No. 5.-WILD BIRDS AT HOME. Second Series. By Chas. Kirk.

No. 6.-FRESHWATER FISHES. Sixty Photographs from Life, by Walford B. Johnson and Stanley C. Johnson, M.A.

No. 7.-TOADSTOOLS AT HOME. Sixty Photographs of Fungi, by Somerville Hastings, F.R.C.S.

No. 8.-OUR TREES \& HOW TO KNOW THEM. Sixty Photographs by Chas. Kirk.

No. 9. -WILD FLOWERS AT HOME, Third Series. By Somerville Hastings, F.R.C.S.

No. 10.-LIFE IN THE ANTARCTIC. Sixty Photographs from Life by Members of the Scottish National Antarctic Expedition. 
No. II.-REPTILE LIFE. Sixty Photographs from Life, by Walford B. Johnson and Stanley $C$. Johnson, M.A.

No. 12.-SEA-SHORE LIFE. Sixty Photographs by the Same.

No. 13.-BIRDS AT THE ZOO. Sixty Photographs from Life, by W. S. Berridge, F.Z.S.

No. I4.-ANIMALS AT THE ZOO. Sixty Photographs by the Same.

No. 15.-SOME MOTHS AND BUTTERFLIES AND THEIR EGGS. Sixty Photographs by A. E. Tonge, F.E.S.

No. I6.-WILD FLOWERS AT HOME. Fourth Series. By Somerville Hastings.

No. 17.-BRITISH MAMMALS. Sixty Photographs from Life, by Oxley Grabham, M.A., T. A. Metcalfe, Sydney H. Smith, and Chas. Kirk.

No. I8.-POND AND STREAM LIFE. Sixty Photographs from Life, by Walford $B$. Johnson and Stanley C. Johnson, M.A.

No. 19.-WILD BIRDS AT HOME. Third Series. By Chas. Kirk.

No. 20.-ALPINE PLANTS AT HOME. First Series.

Sixty Photographs by Somerville Hastings, F.R.C.S.

No. 21.-FOSSIL PLANTS, Sixty Photographs by E.

A. Newell Arber, M.A., F.L.S., F.G.S.

No. 22.-ALPINE PLANTS AT HOME. Second Series. By Somerville Hastings.

No. 23.-OUR FLOWERING SHRUBS AND HOW TO KNOW THEM. Sixty Photographs by Chas. Kirk.

No. 24.-WILD BIRDS AT HOME. Fourth Series. Sixty Photographs by Peter Webster.

No. 25.-TOADSTOOLS AT HOME. Second Series. By Somerville Hastings.

No. 26.-WILD LIFE IN THE FALKLAND ISLANDS. Sixty Photographs from Life, by Arthur F. Cobb, B.A.

No. 27.-BIRDS AT THE ZOO. Second Series. By W. S. Berridge.

No. 28.-ANIMALS AT THE ZOO. Second Series. By W. S. Berridge.

Others in Preparation.

price 6D. Net each Volume, Pogtage 1D. Each. GOWANS \& GRAY, Ltd., London \& Glasgow 


\section{The First Three of Gowans's Practical Picture Books}

Price in Parchment Cover, 6d. net each, post free $7 \mathrm{~d}$.

No. r. Ambulance Illustrated.

BY WM. CULLEN, M.D.

Sixty Photographs by W. M. Warneuke, illustrating First Aid, with Concise Notes by the Author.

No. 2. Golfing Illustrated. BY G. W. BELDAM.

Sixty Action-Photographs of Famous Golfers, illustrating the Different Strokes in the Game, with Short Notes on the Players' Styles by John L. Low.

None of these Photographs has appeared in "Great Golfers."

No. 3. Cricket Illustrated.

By G. W. BELDAM.

Sixty Action-Photographs of Famous Cricketers-Forty of Batters, and Twenty of Bowlers-with Short Notes on the Players' Styles by the Author.

None of these Photographs has appeared in "Great Bowlers" or "Great Batsmen."

LONDON AND GLasgow: Gowans \& Gray, LTD. 


\section{NOVELTIES, \\ CHRISTMAS, I 9 Io.}

1. MARY QUEEN OF SCOTS. A Poem by Henry Glassford Bell. With four photogravure illustrations after Robert Herdman, R.S.A. Paper Cover, $6 \mathrm{~d}$. net.

2. MASTERPIECES OF LYRICAL TR ANSLATION. Uniform with "Lyric Masterpieces by Living Authors." Parchment Cover, 6d. net.

3. LES CHEFS-D'GUVRE LYRIQUES DE VICTOR HUGO. Choisis par Auguste Dorchain. Parch. ment, 6d. net; Cloth, 18. net; Leather, 2s. net.

4. TURNER'S LIBER STUDIORUM. Miniature Edition, with all the unpublished plates. Paper 18 net; Cloth, 1s. 6d, net; Leather, 2s. 6d. net.

5. CLYDE SONGS AND OTHER VERSES, by J. J. B., author of "Wee Macgreegor." Cloth, 25. 6d, net. Limited Edition on Handmade Paper, 5s. net.

6. THE GARDEN OF SHADOWS. A Novel by James MacNab, 2s. 6d. net.

Also New Volumes in other Series (See Art Books, Nature Books, etc.).

LONDON \& GLASGOW : GOWANS \& GRAY, LTD. 


\title{
THE LIFE OF
}
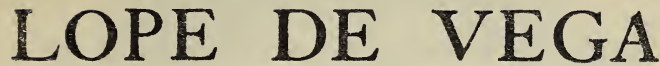

\section{The Great Spanish Dramatist}

\author{
BY HUGO A. RENNERT \\ PROFESBOR OY ROMANIC LANGUAGES AND LITERATURE M TK \\ UNIVERSITY OF PENWSYLVANIA
}

THERE has been no life of Lope de Vega published in English since that by Lord Holland nearly 100 years ago.

Professor Rennert has been able to take advantage of the labours of all previous workers in the same field, and has in addition been fortunate above all his predecessors In that documents were published for the first time within the last few years by Señor Perez Pastor, which threw a flood of light on many dark points in Lope's career.

He has made full use of all fresh data, and has endeavoured to record every known fact in the life of the poet. His biography is therefore the most thorough yet published, and in the opinion of Mr. Fitzmaurice-Kelly, the leading English anthority, his biography is the standard life. It is consequently indispensable to every Important library.

Demsy 8vo, Cloth, Gilt Top. Price, 12s. 6d. net

GOWANS \& GRAY. Ltd., London \& Glasgow 


\section{LOPE DE VEGA \& THE SPANISH DRAMA}

BEING THE TAYLORIAN LECTURE (I9O2)

BY JAMES FITZMAURICE-KELLY

An extremely eloquent essay, of great interest to all students of the drama.

Paper Covers, Is. net. Postage, $\mathbf{I}$.

\section{MRS. MCCRAW}

By SAMUEL MACPLOWTER, RULING Elder

The 'Kailyard' as it really is; not the idealised presentment of it as given in the novels of J. M. Barrie and Ian Maclaren. Clever character sketches of a most impudent woman, by a resident somewhere in the Thrums district. Price, Is. net. Postage, $\mathrm{I} \frac{1}{2} d$.

\section{THE BIRTHDAY BOOK OF SOLOMON GRUNDY}

ILLUSTRATIONS BY A. S. BOYD LETTERPRESS BY WILL. ROBERTSON

Scotsman-'The book is really very funny, and will unquestionably be popular.'

Pwnch-'Solomon Grundy's Birthday Book's a charming publica. tion. Devised by Robertson and Boyd for people's delectation.'

Prices, 1s. and 1s. 6d. Postage, $1 \frac{1}{2} d$.

GOWANS \& GRAY, LTD., LONDON AND GLASGOW 


\section{The Family Bookshelf, No. 1.}

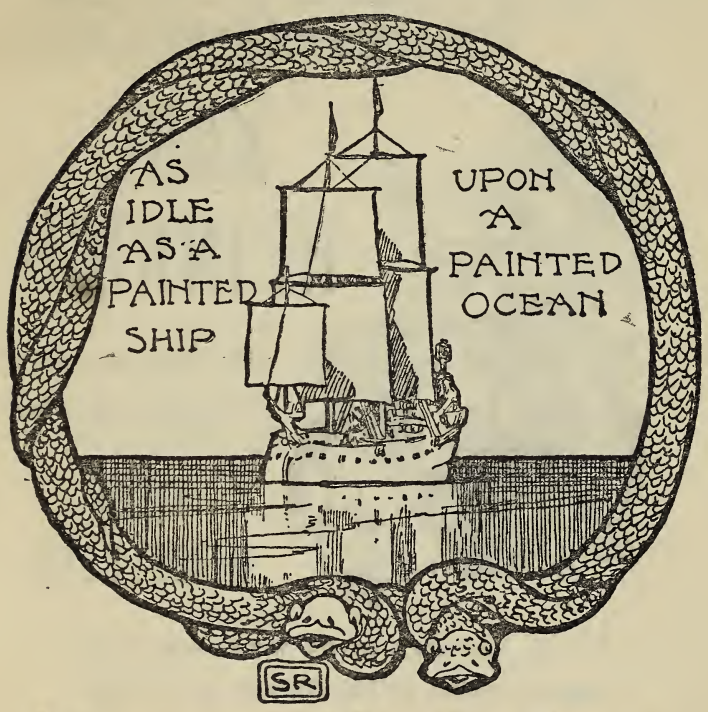

\section{Areasury of English Verse}

Selected by ADAM L. GOWANS, M.A. With decorative title-page and end-papers, frontispiece, 50 full page and over 100 smaller illustrations by STEPHEN REID.

A most delightful volume to handle; beautifully illustrated and printed.

Price, 5/- Net. Postage, 4d. Extra.

GOWANS \& GRAX, Ltd, London \& Glasgow. 
Great Continental Successes, No. 1.

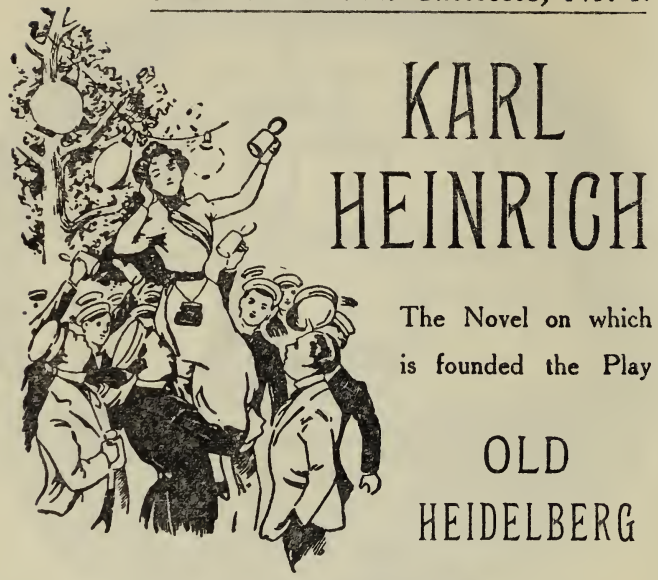

WHICH HAS BEEN GIVEN WITH SUCH VERY great SUCCess by Mr. George Alexander

BY W. MEYER-FÖRSTER

WITH I3 ILLUSTRATIONS

THE ONLY TRANSLATION

Cloth, 3s. 6d. net

GOWANS \& GRAY, LTD., LONDON AND GLASGOW 
Gowans's Nature Books, No. 25

\title{
Toadstools at Home
}

\author{
SECOND SERIES
}

ROBERT MACLEHOSE \& CO. LIMITED, PRINTERS, GLASGOW

BLOCKS BY HISLOP \& DAY, EDINBURGH

PAPER BY ALEX. COWAN \& SONS, LIMITED, EDINBURGH 
AGARICUS [AMANITA] MUSCARIUS

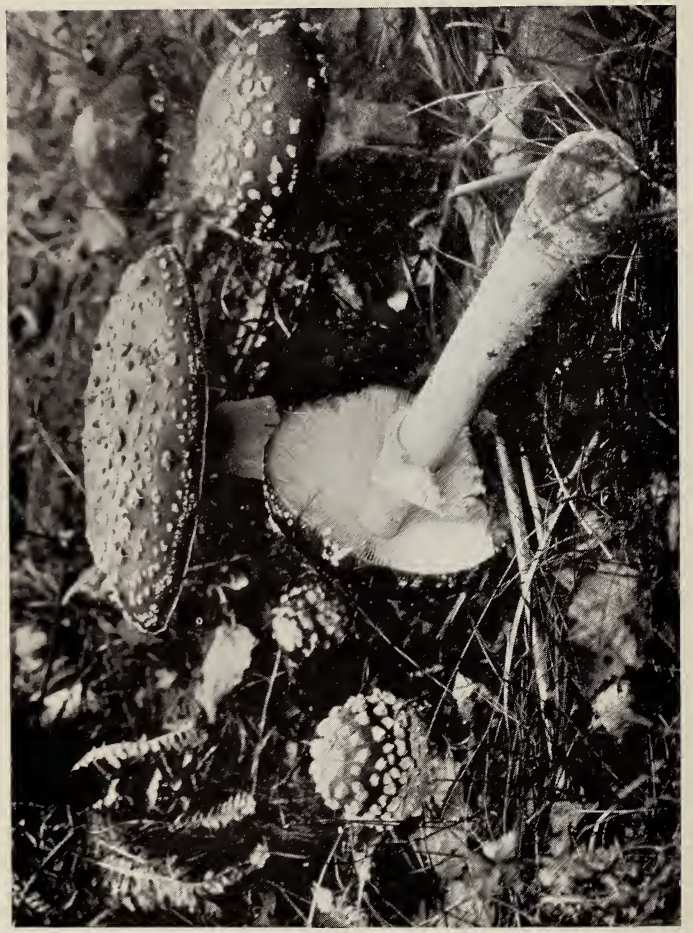

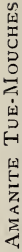

글

告 $x$

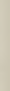




\section{TOADSTOOLS}

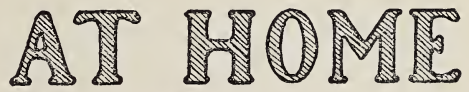

\section{SECOND SERIES}

Sixty photographs from nature by Somerville Hastings, F.R.C.S., of British Fungi

GOWANS \& GRAY, LTD.

5 Robert Street, Adelphi, London, W.C. 58 Cadogan Street, Glasgow 

THE reception accorded to the first series of "Toadstools at Home" has encouraged the publishers to issue a second series of photographs, also by Mr. Hastings, which they trust will be as heartily appreciated as was the former set.

Lantern-slides of any of the photographs in this book, or in the previous series of "Toadstools at Home," can be obtained from Messrs. Newton, Opticians, 3 Fleet Street, London, E.C. 


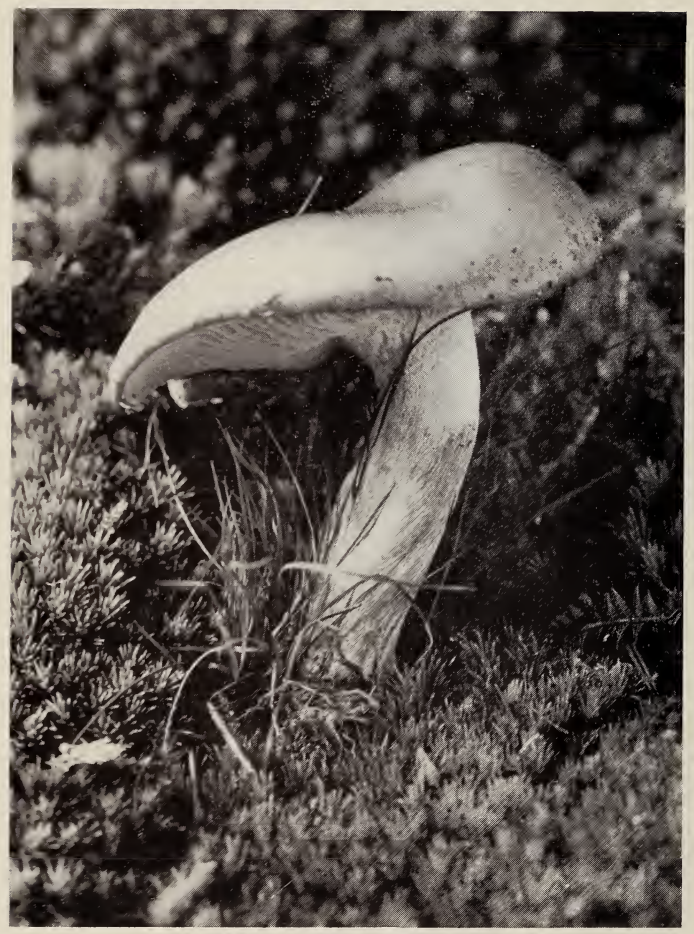

The Wood Blewit

NackTer Ritterscuivamm

AgARIC NU

$$
\times \frac{2}{3}
$$




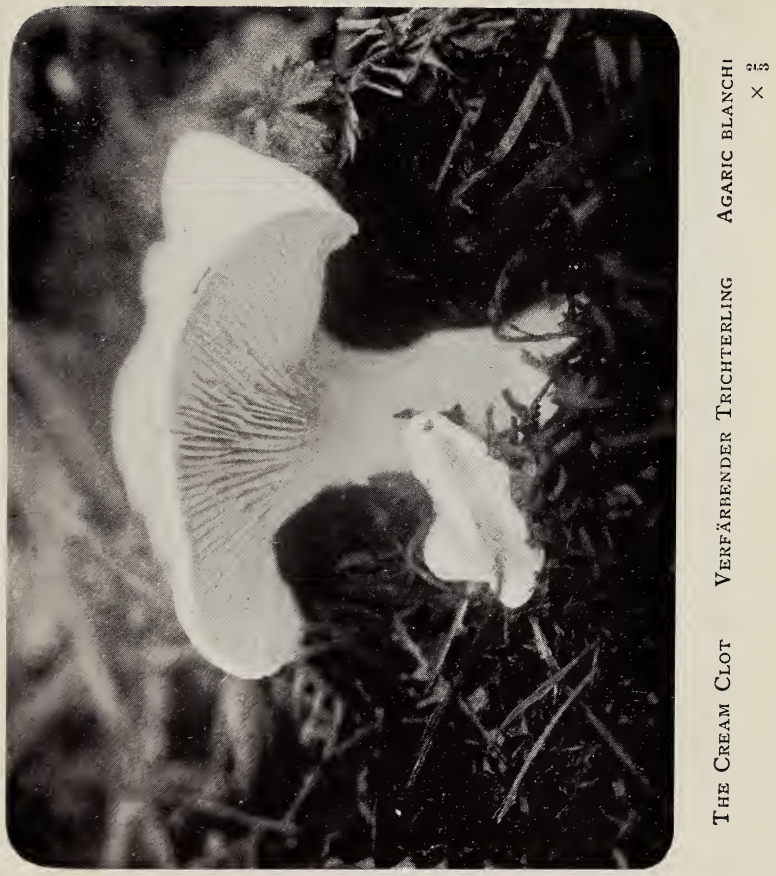


AGARICUS [CLITOCYBE] TUBA

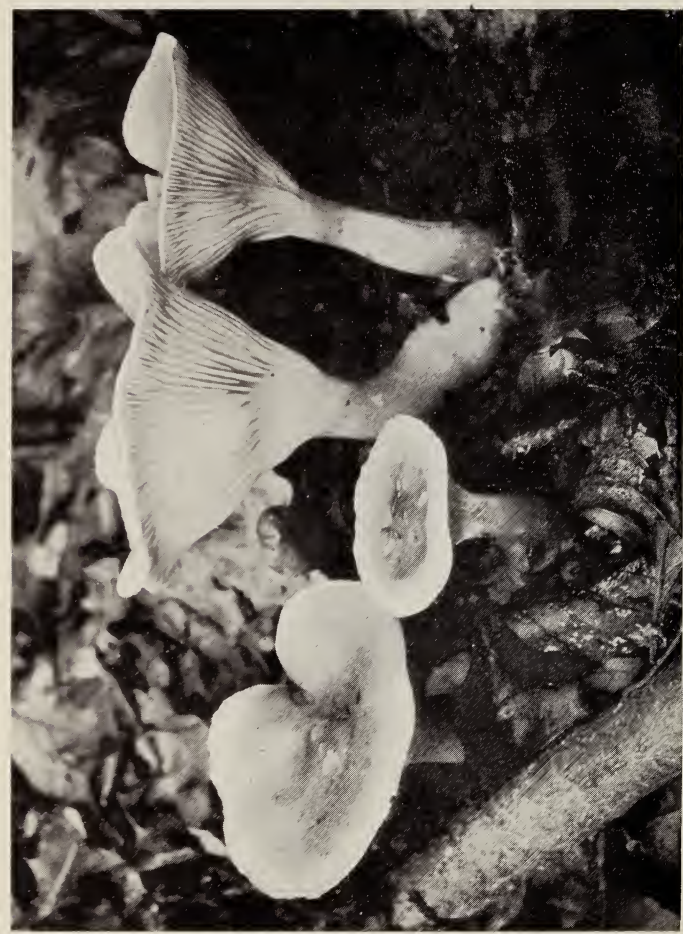

대욜

资

0

吾 


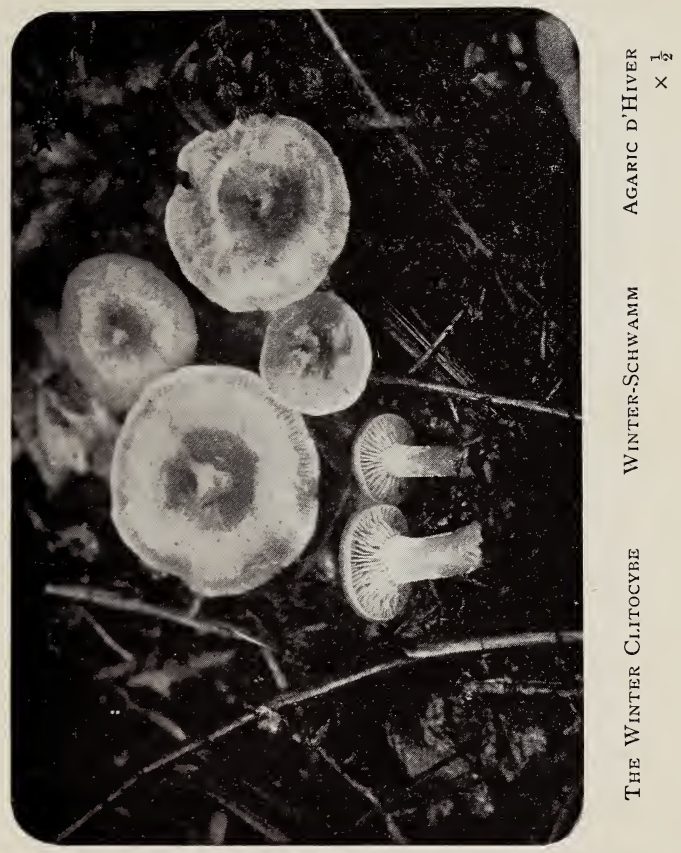




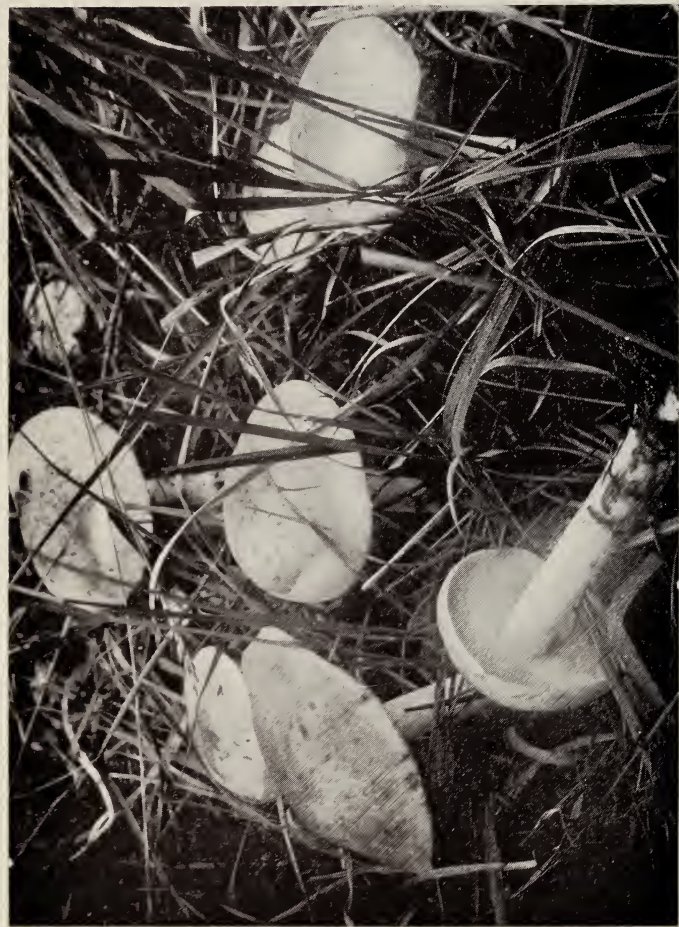

到

告

(1) 


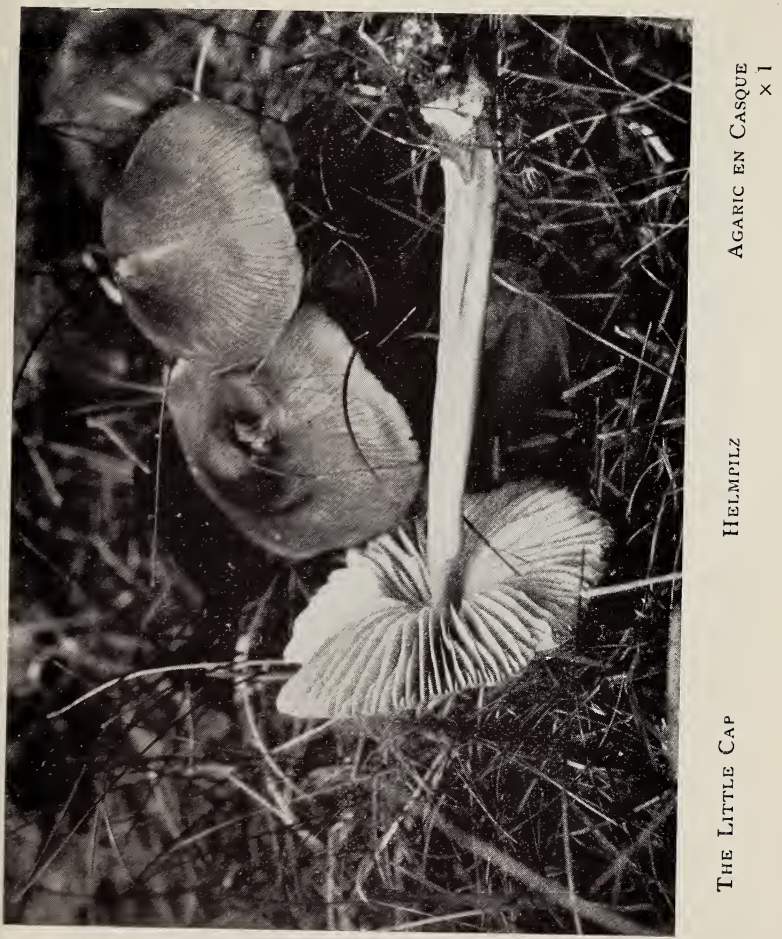




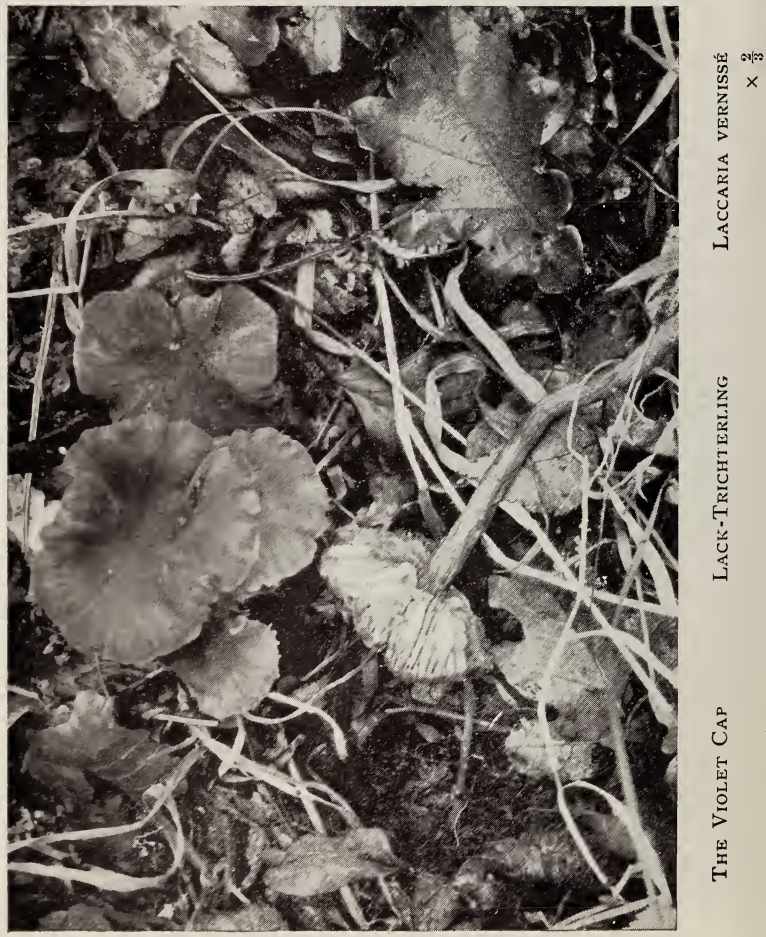




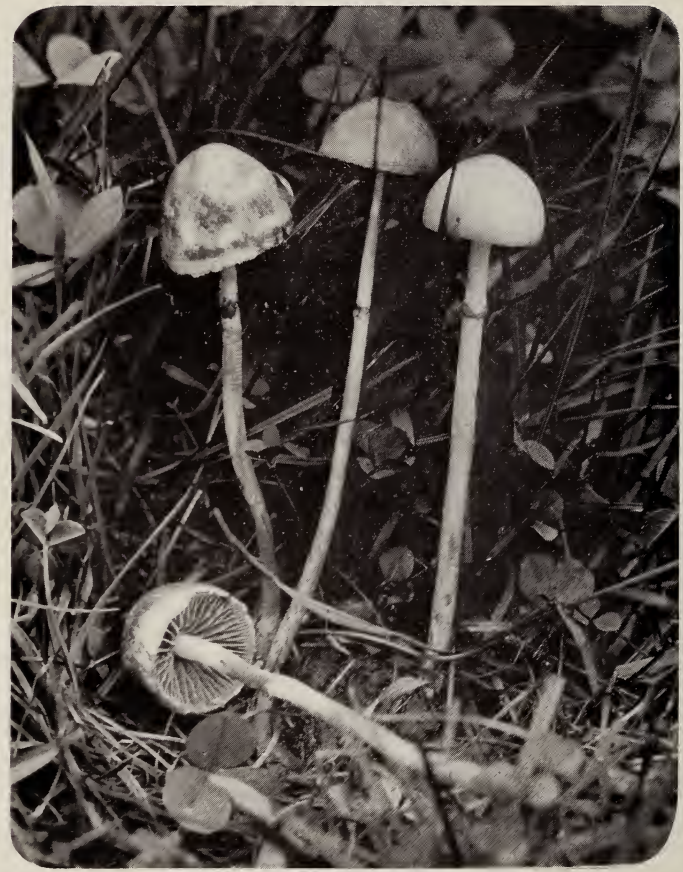

The Dung Stropharia

Agaric EXCRÉMENTIEI. M IST-GÜRTELPILZ $\times \frac{2}{3}$ 


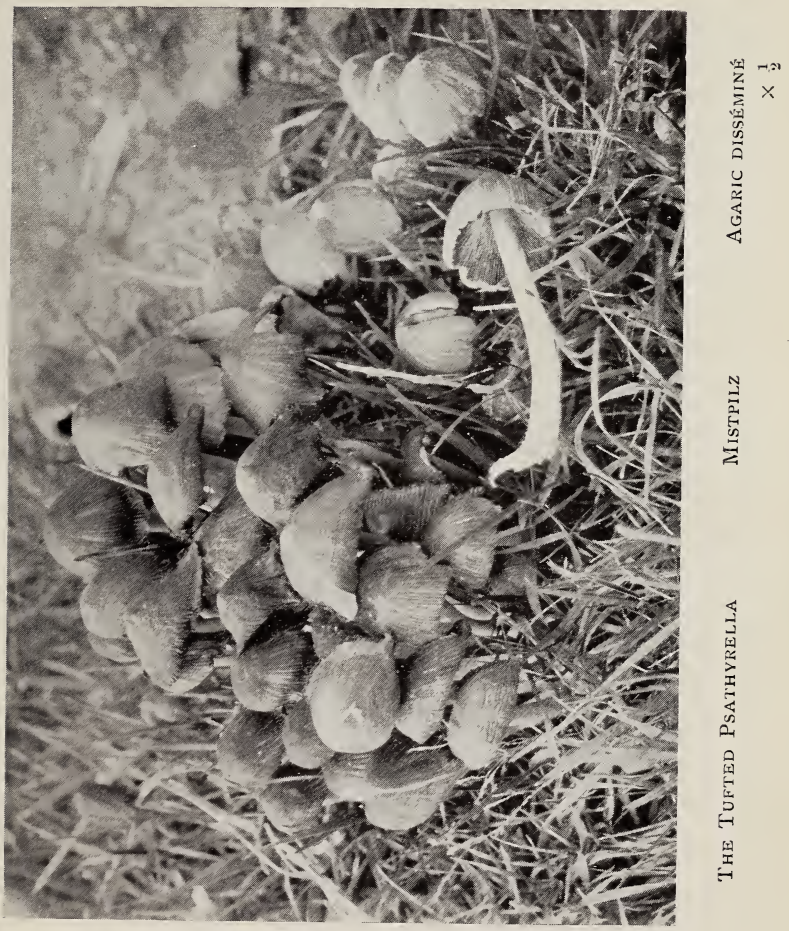




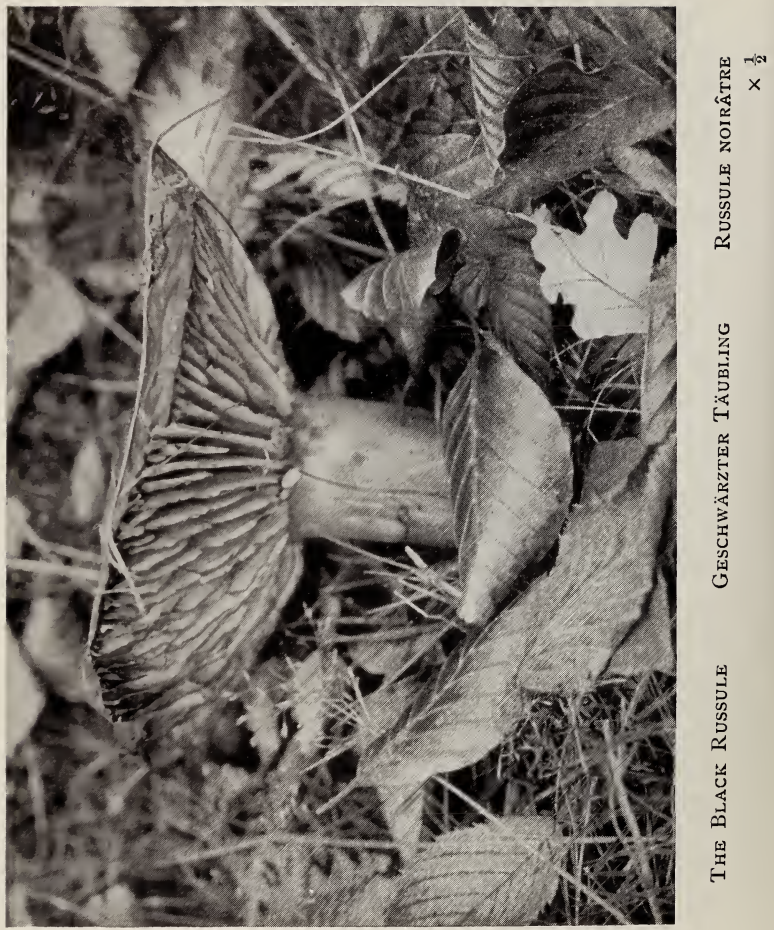




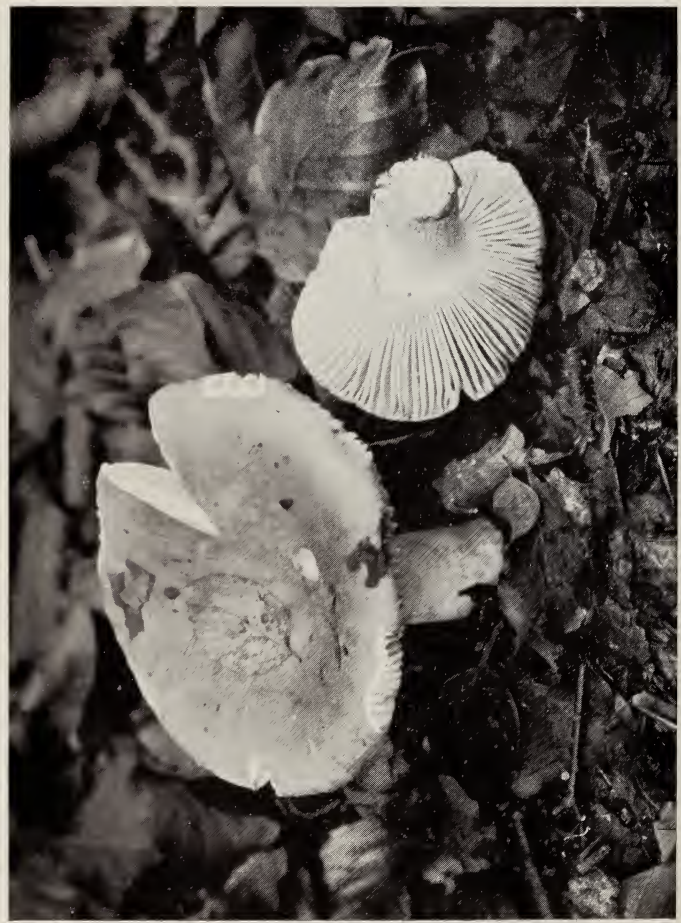

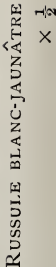

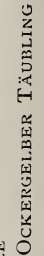

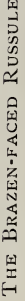




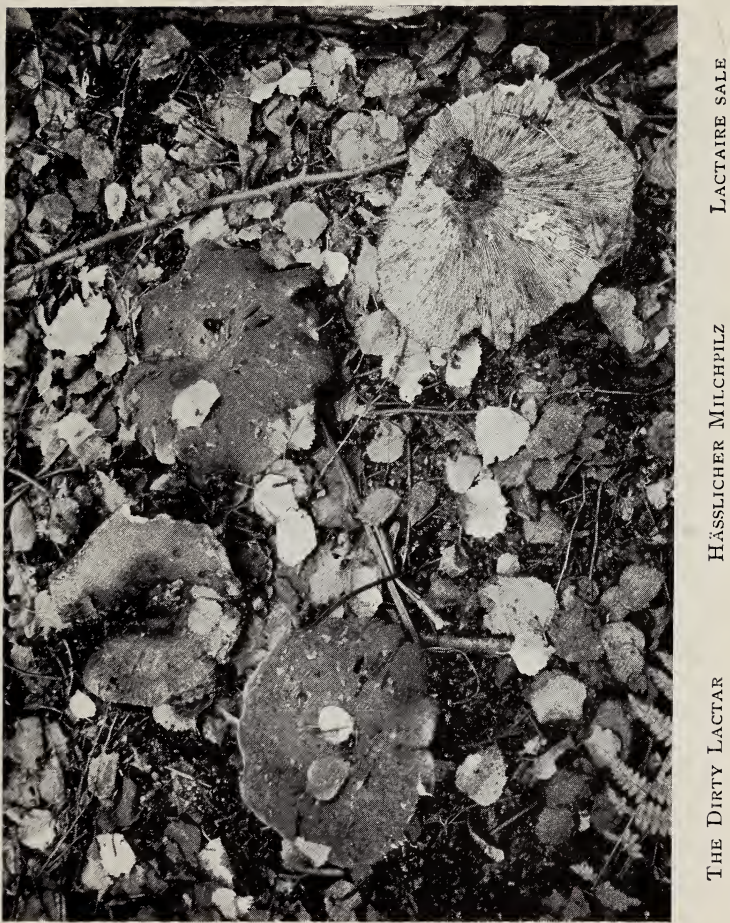




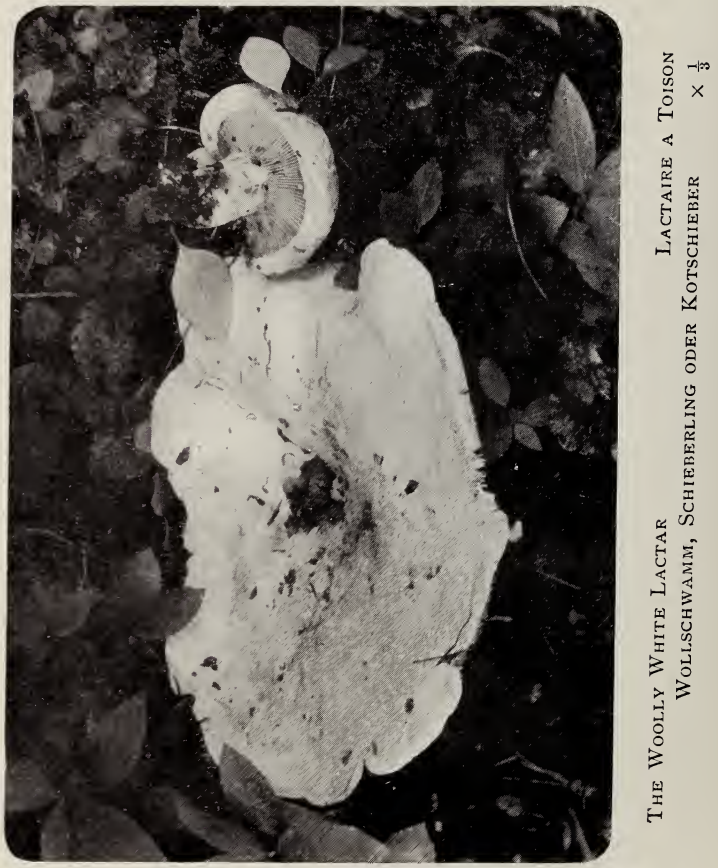




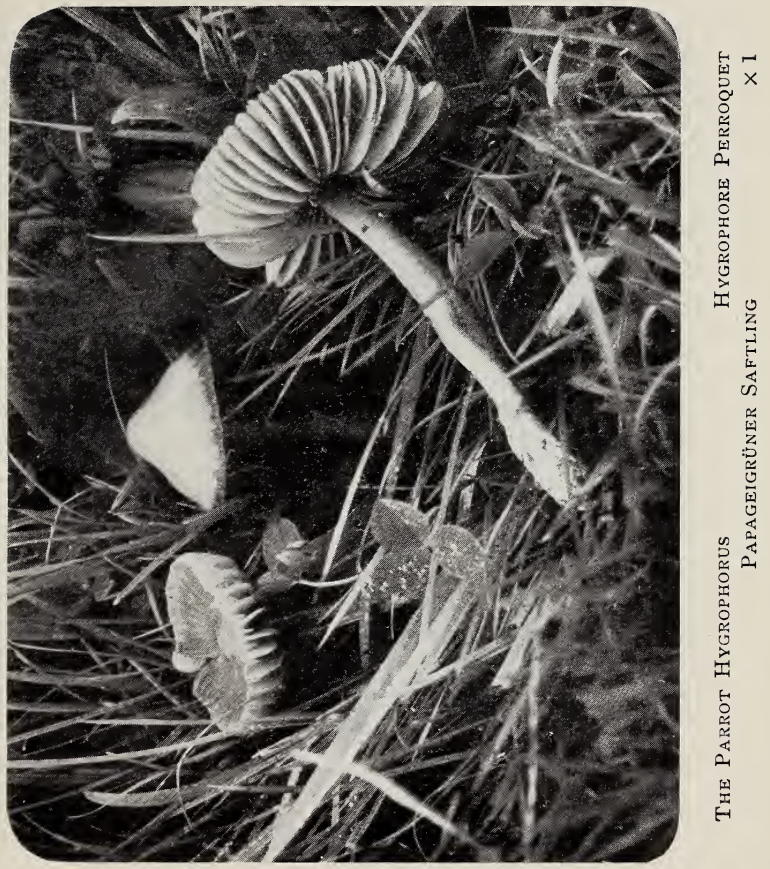




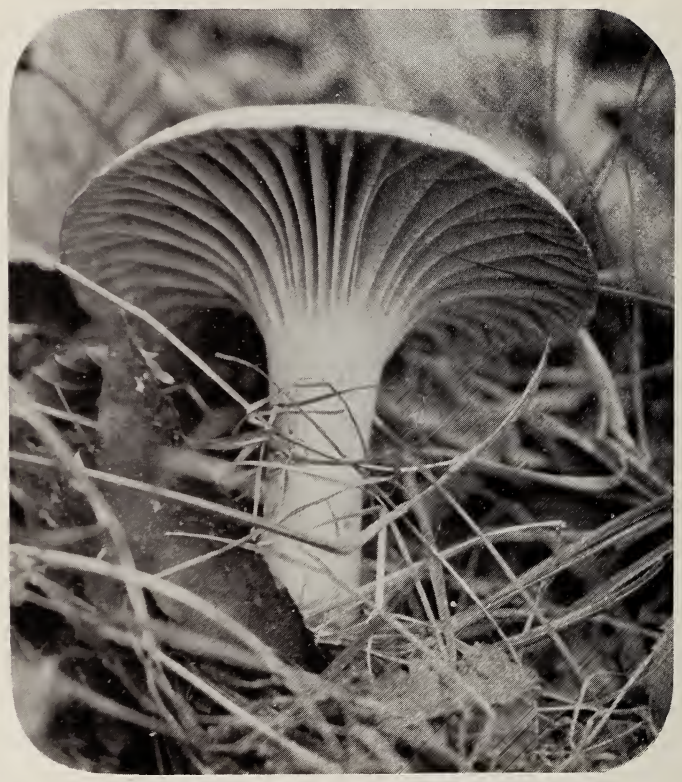

The Meton Hygrophorus

Hygrophore des Prés

WIESEN-GARNELENPILZZ $\times 1$ 


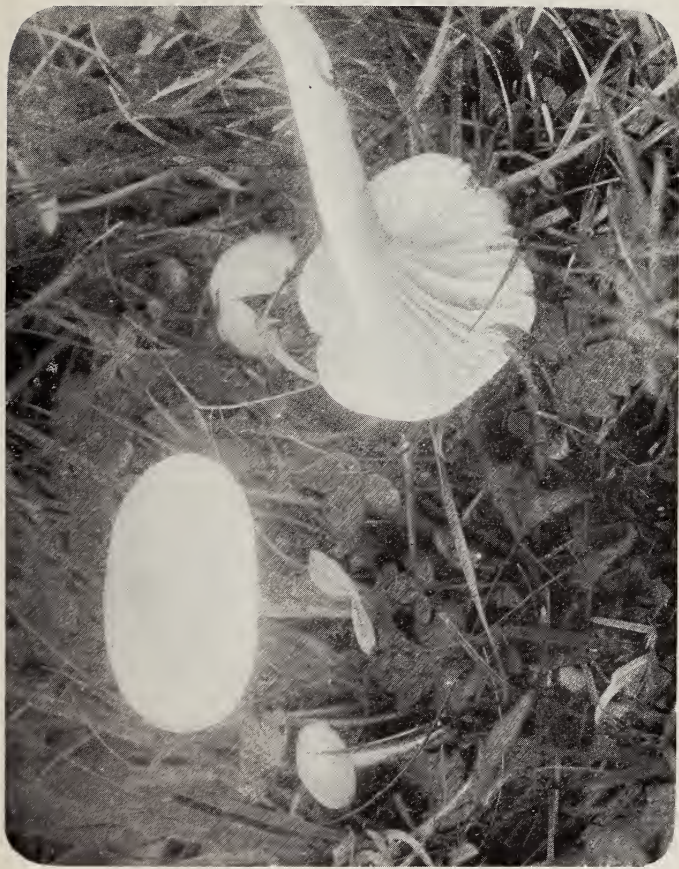

热

售

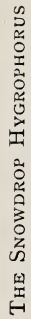




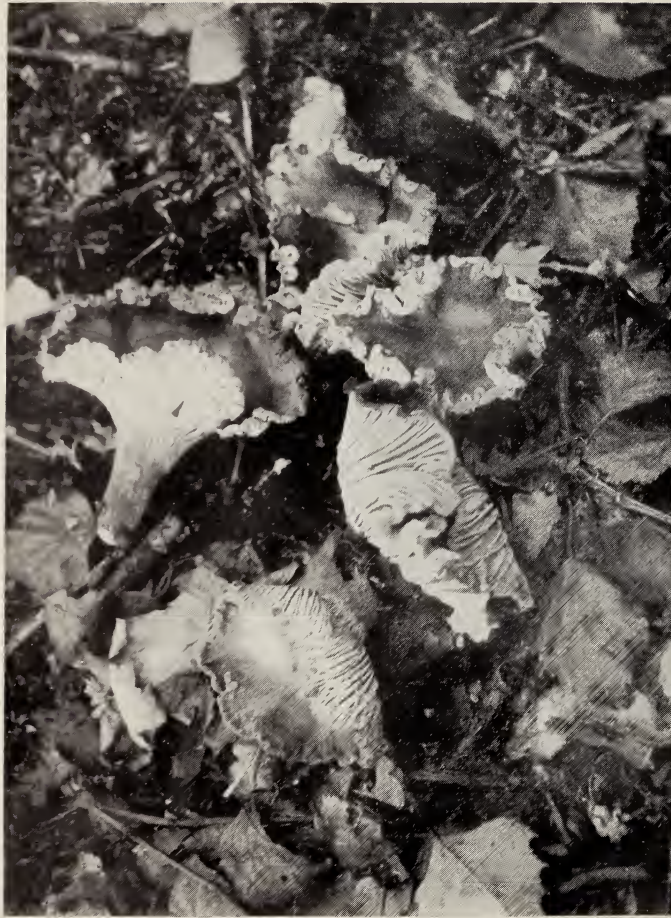




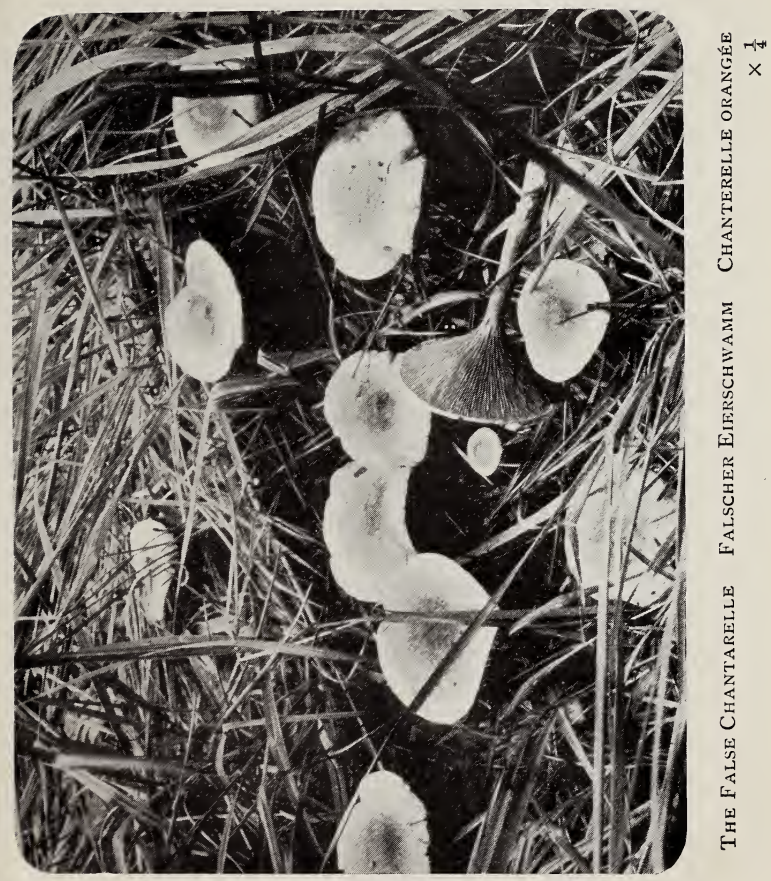




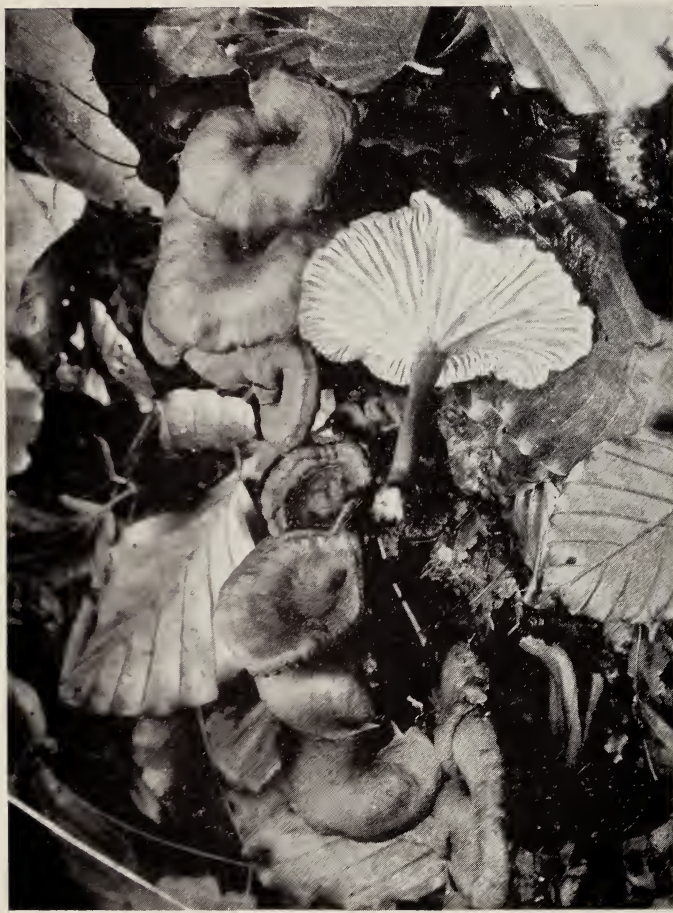

사요

象

동

I

学

(a)

(1)

논

垔

点

(8)

U

:

(5)

돈

(ㄷ)

$\Rightarrow$

(I)

4

z

荘

(5) 


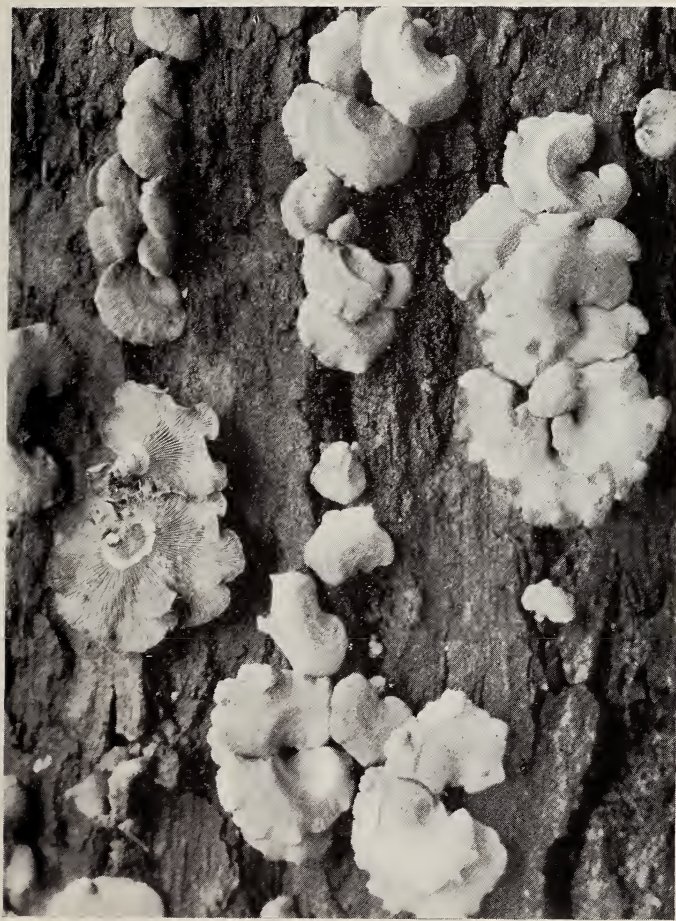

䎹



क 


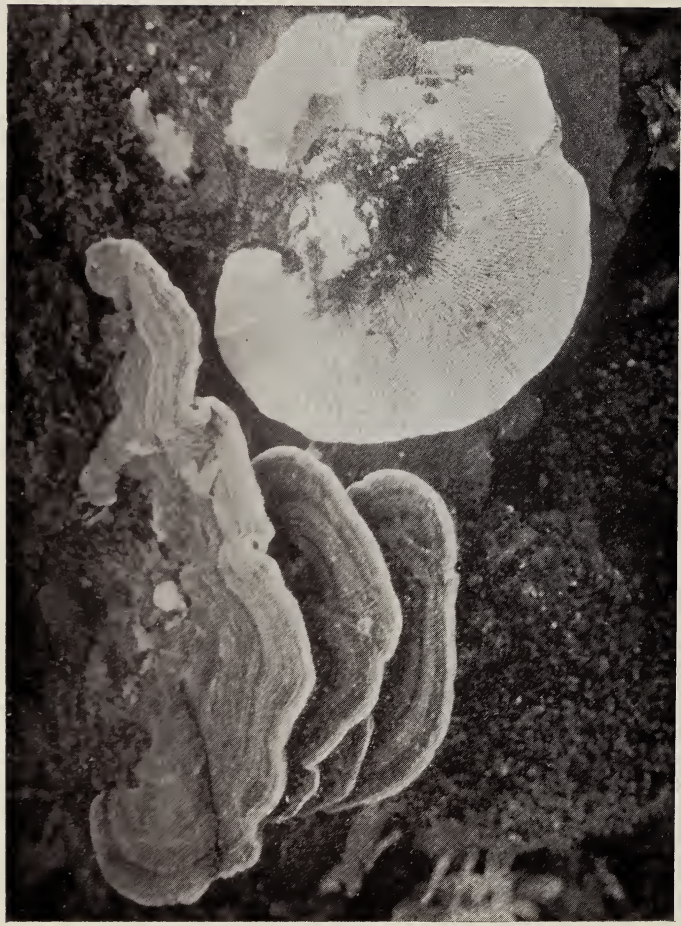

20

告

告 


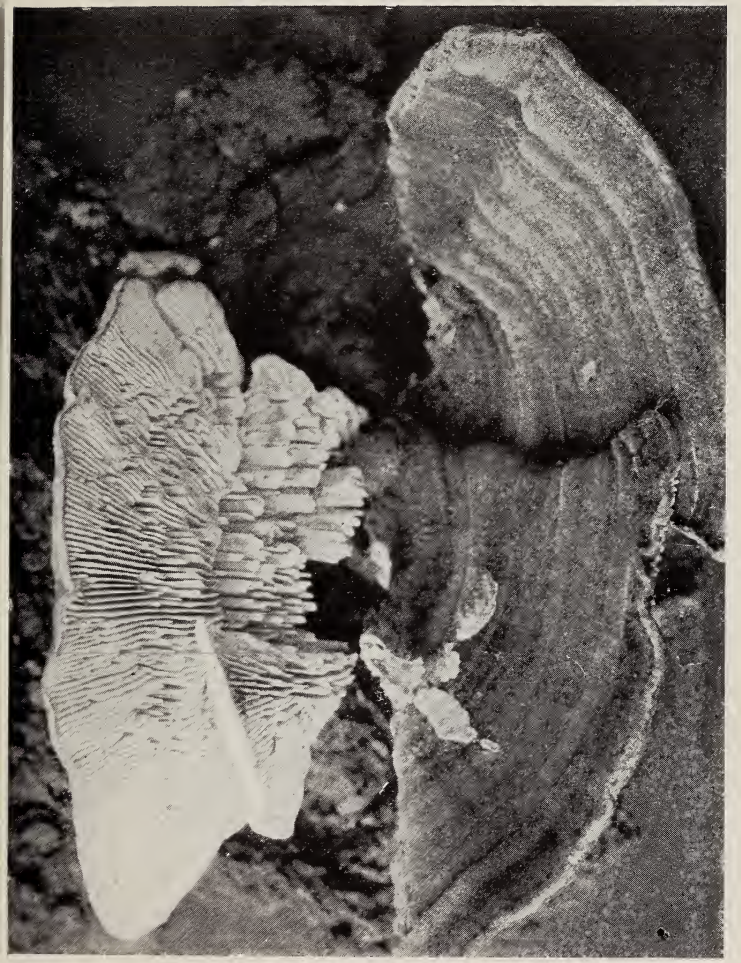

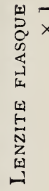

年

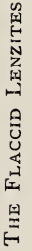




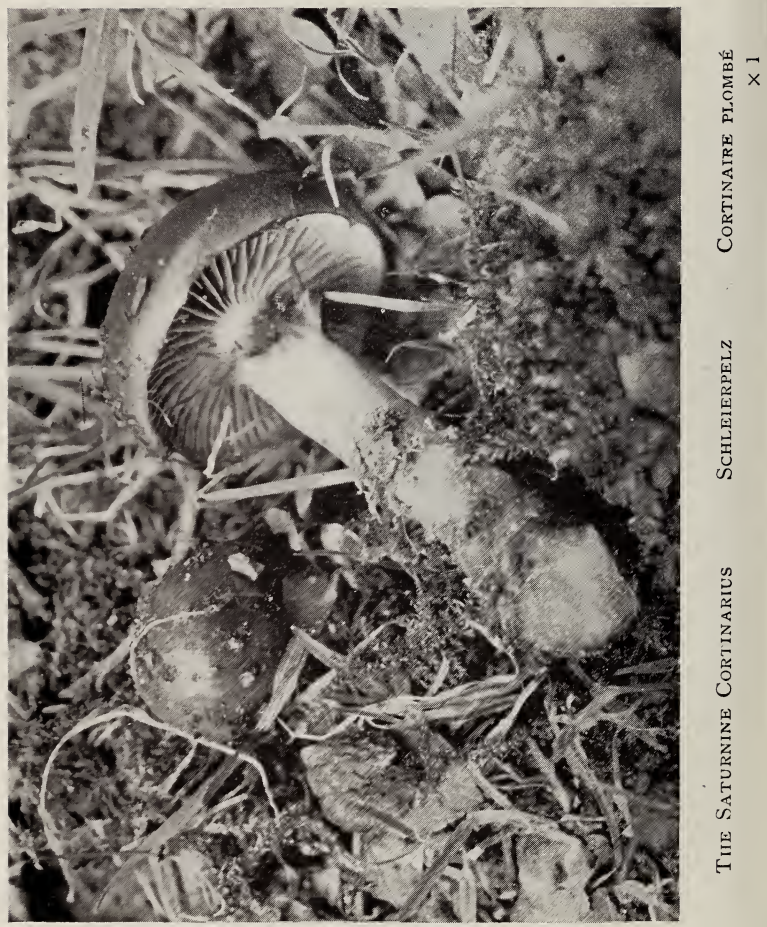




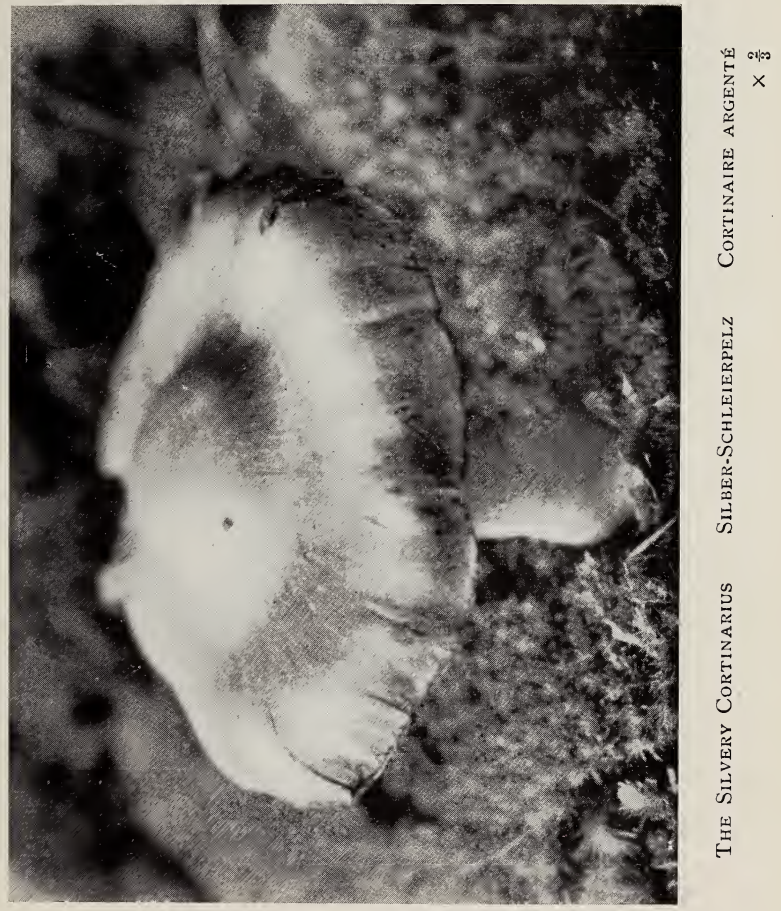




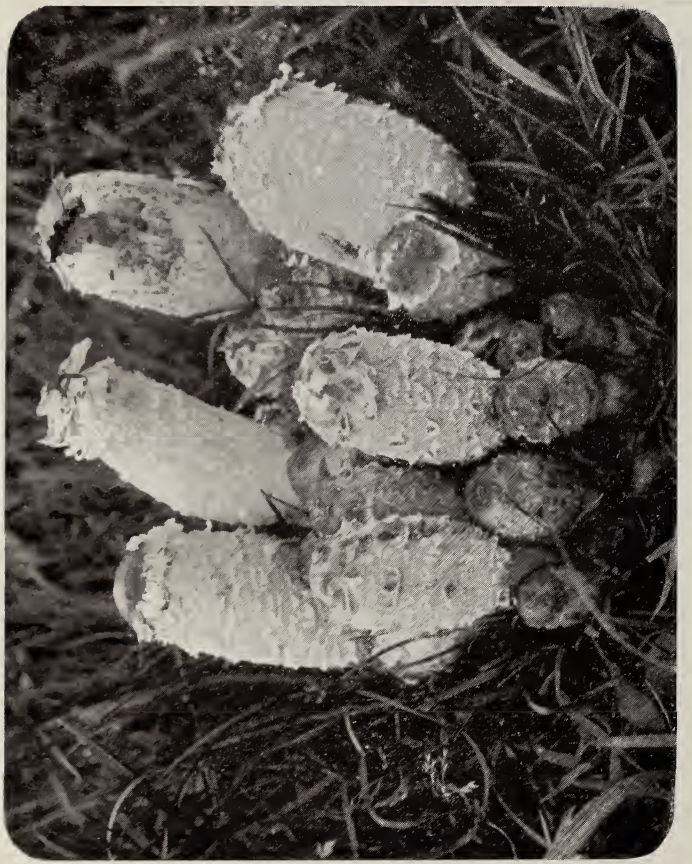

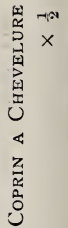



نं 


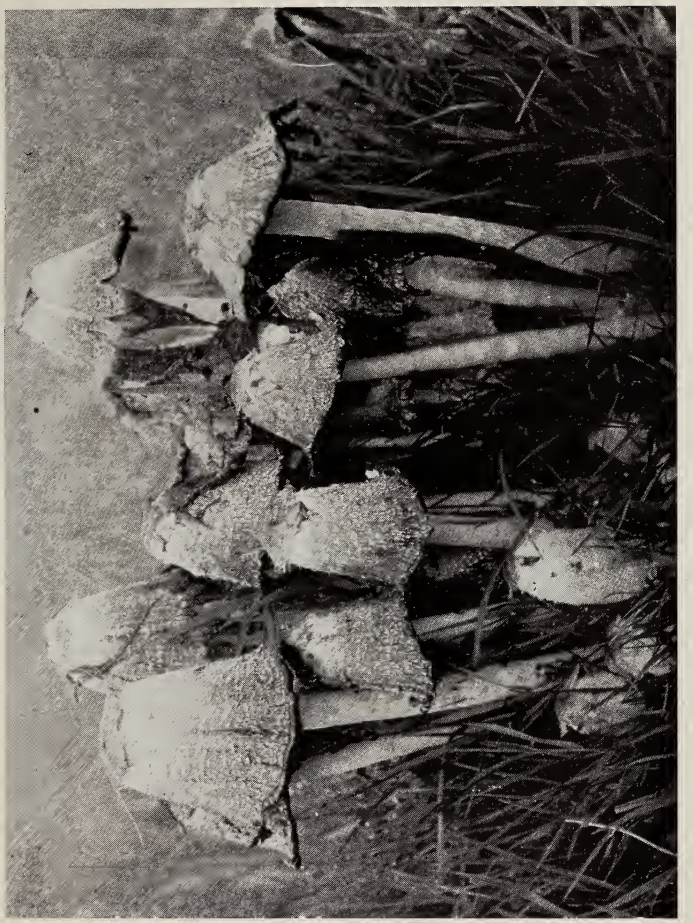

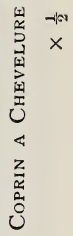

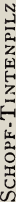

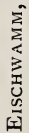

ت્ન 


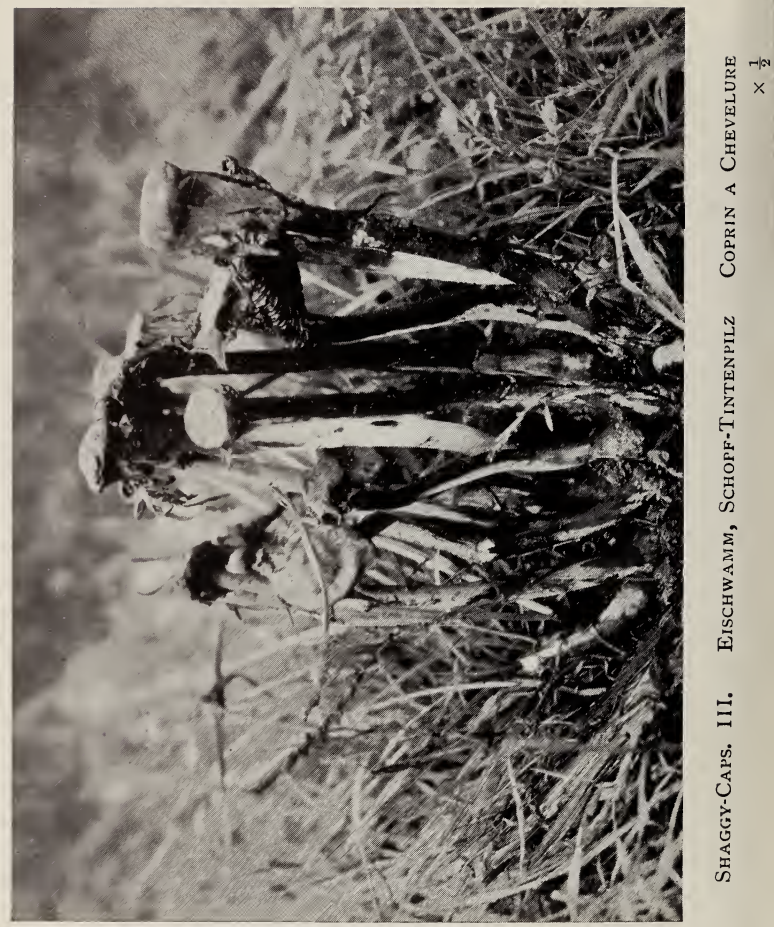




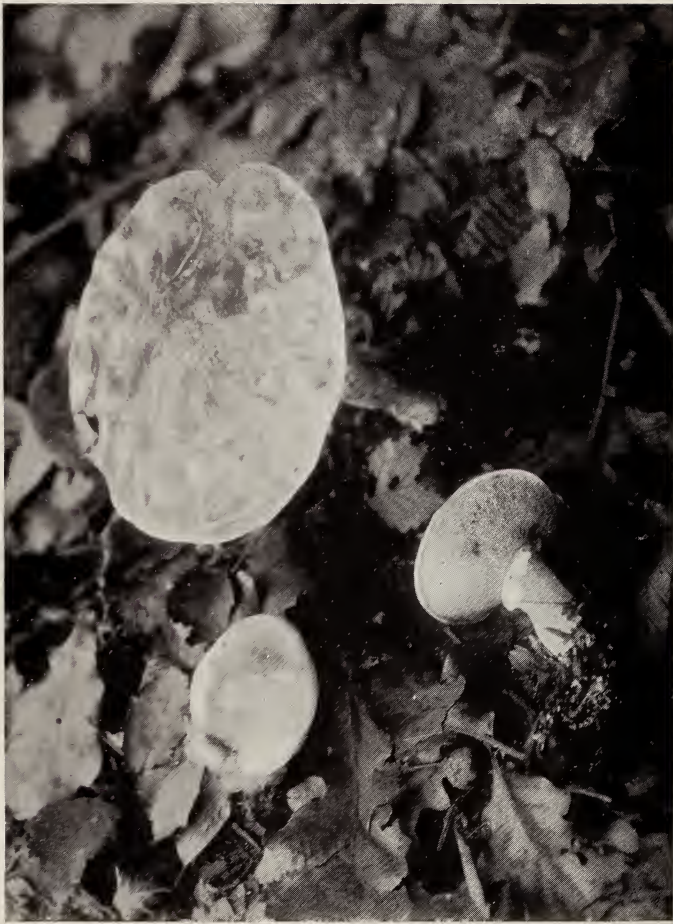

골

荃 


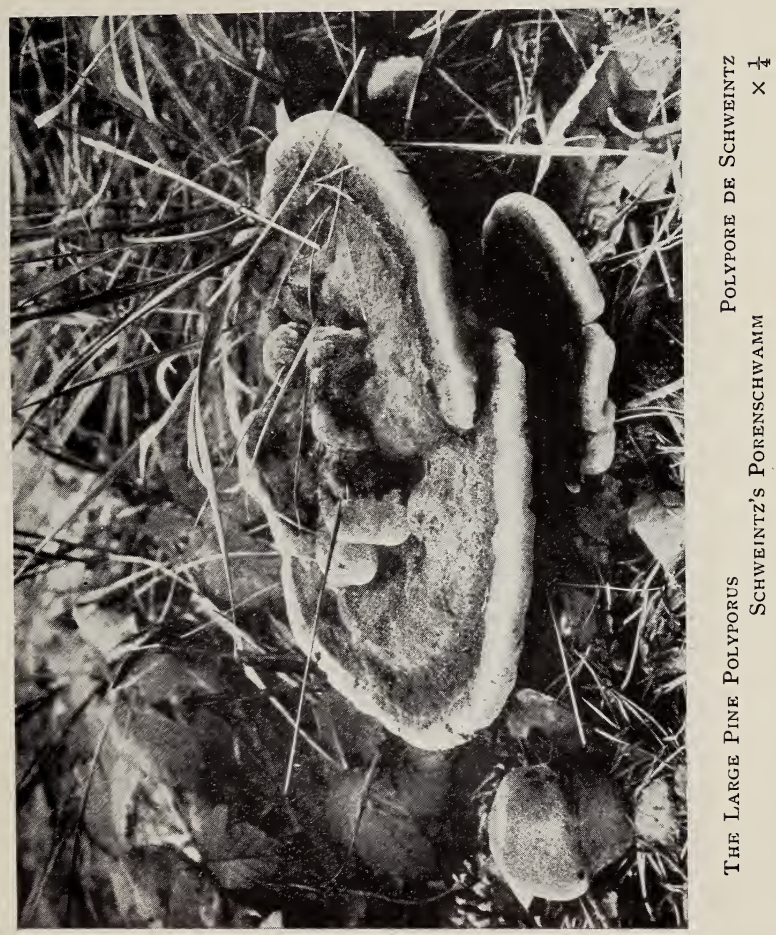




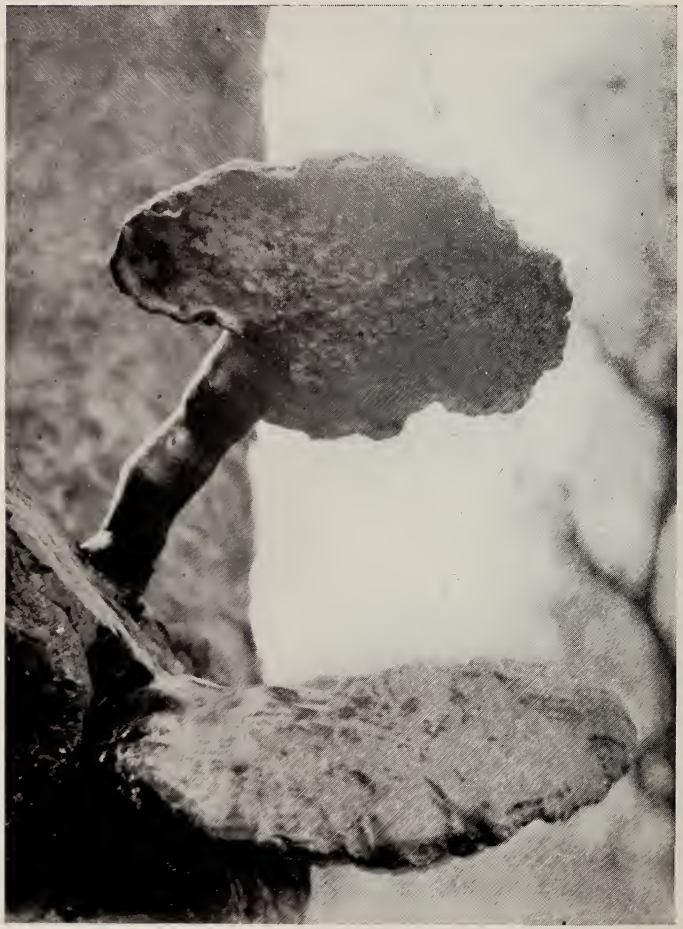

The Varnished Polyporus

POLYPORE LUisAnt Glanz-Porenschwamm $\times \frac{1}{2}$ 


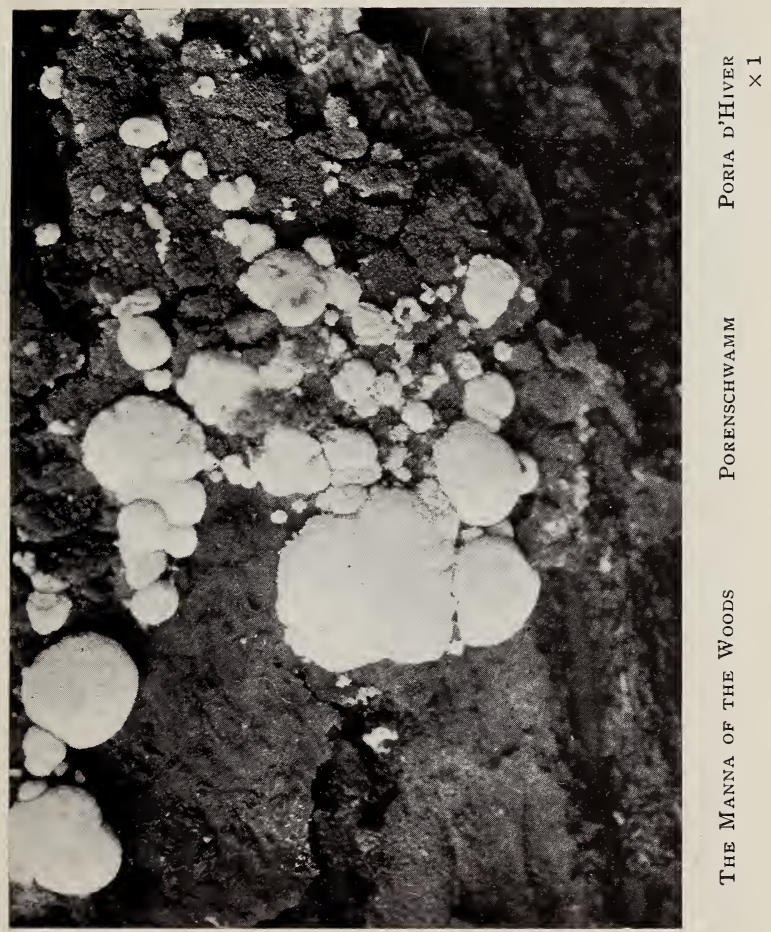




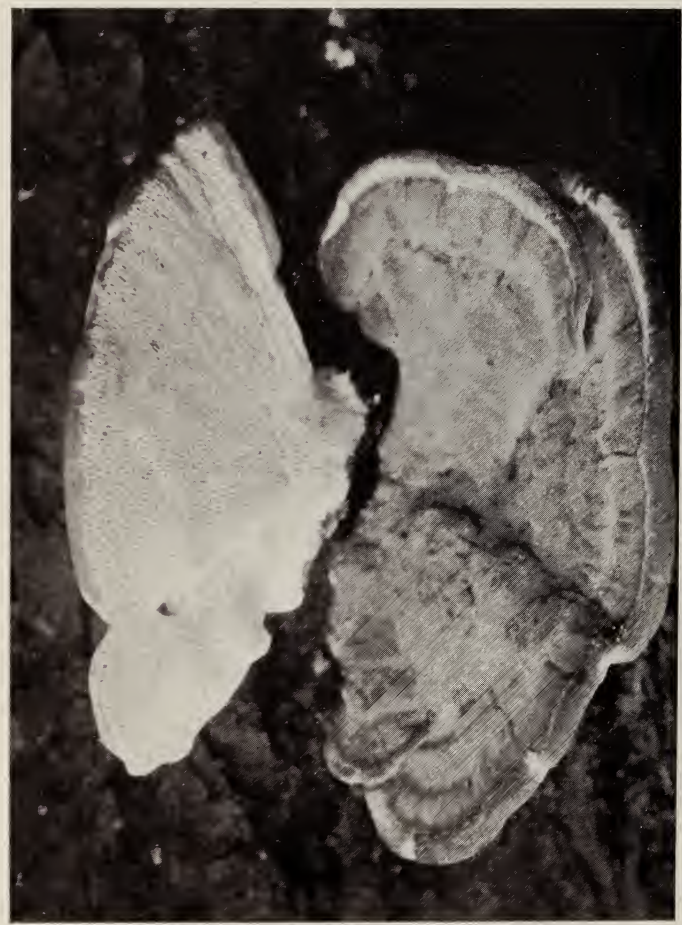

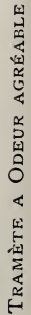

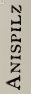

(1) 


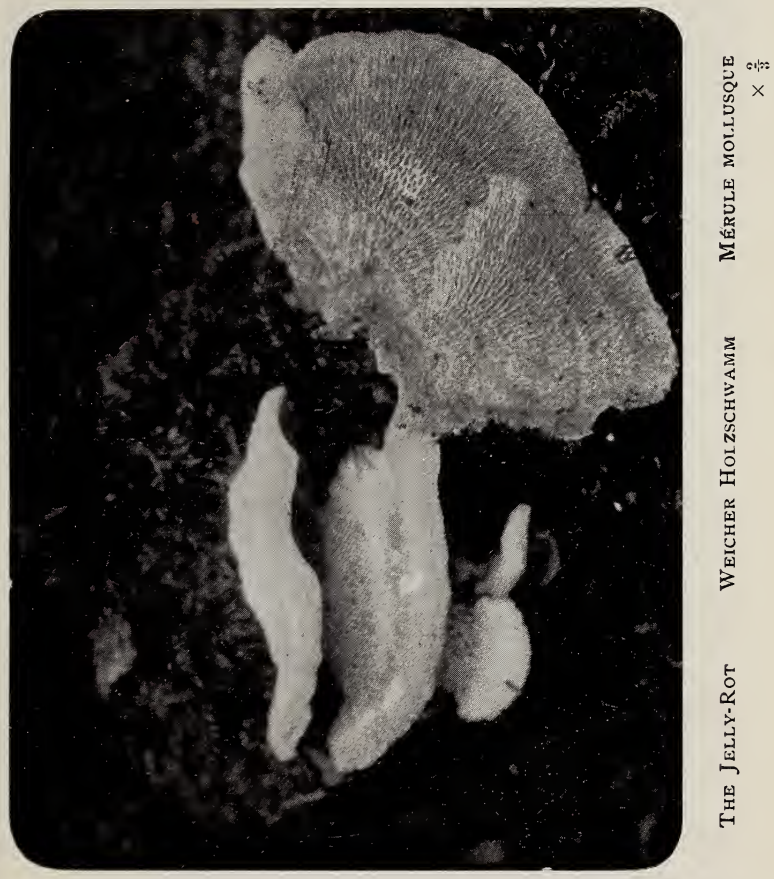




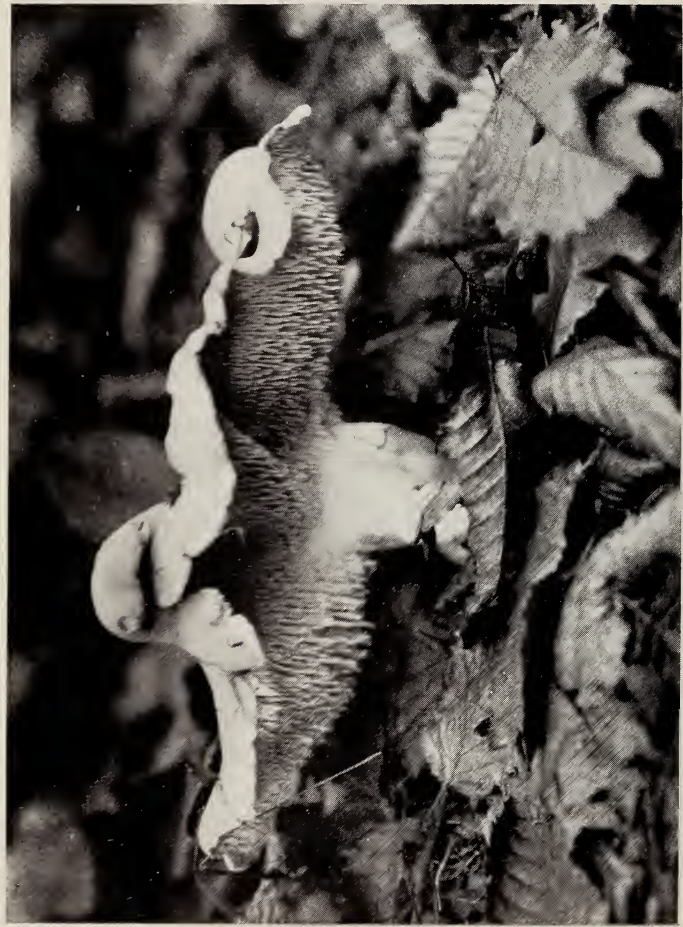





30

息 


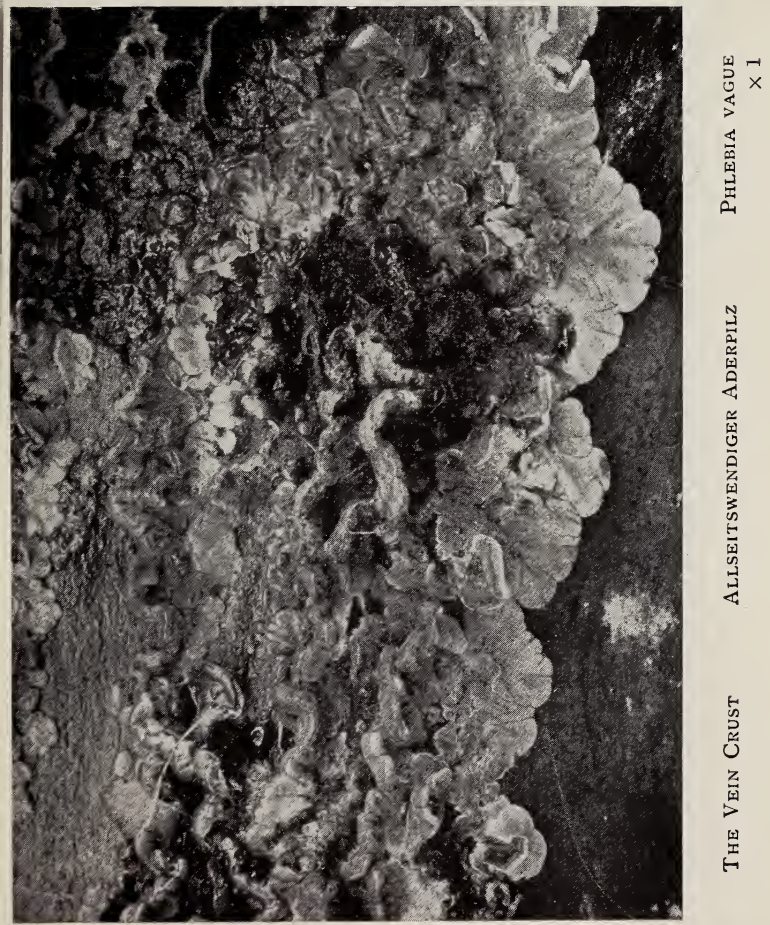




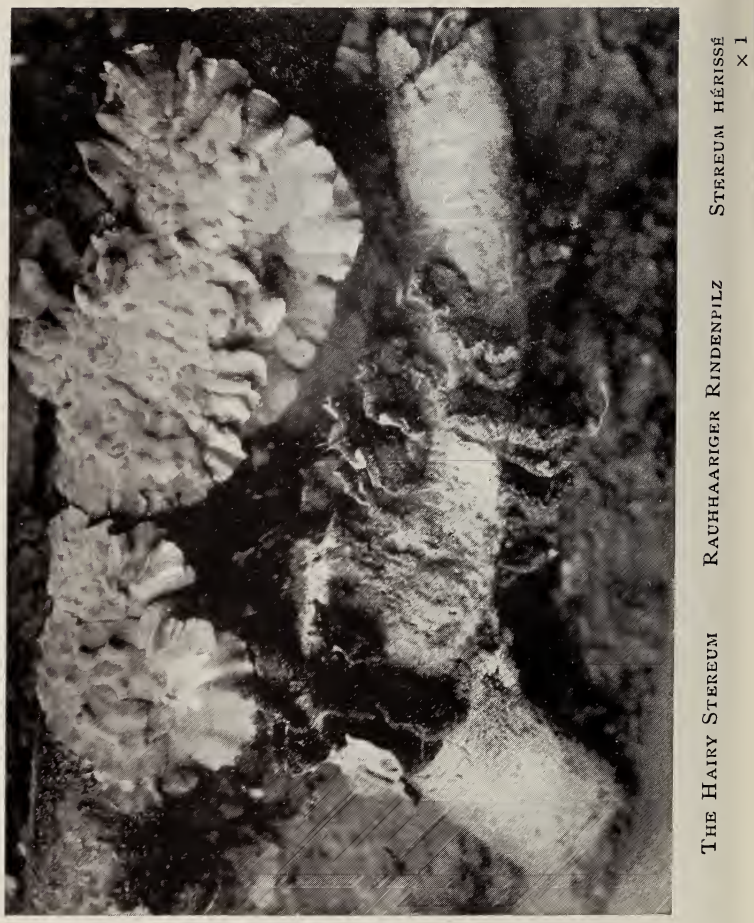




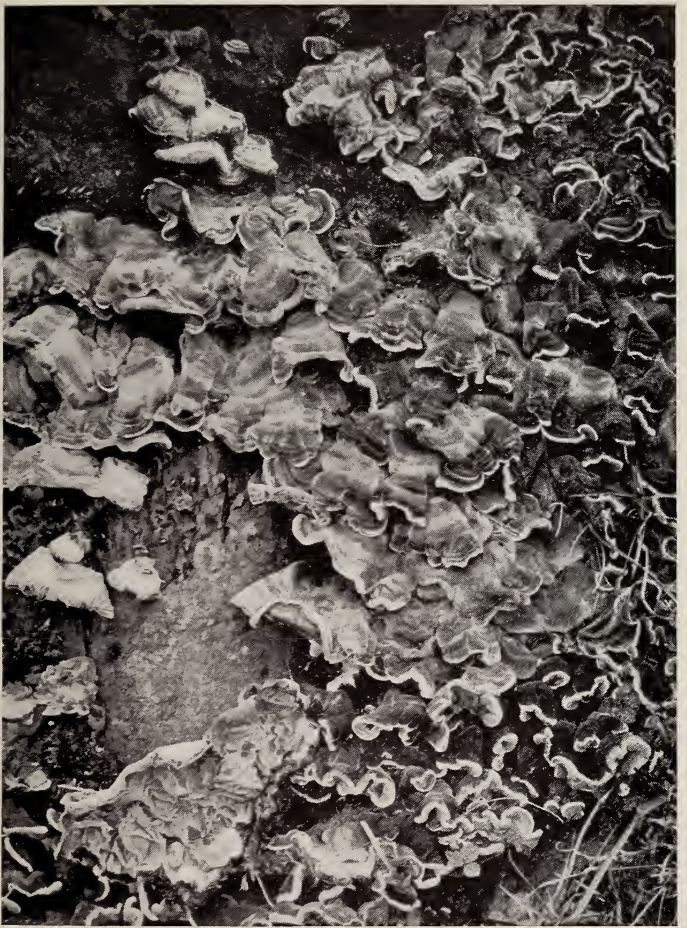

The Purple Stereum

STEREUM POURPRE

PURPURROTER RindeNPILZ

$\times \frac{1}{3}$ 


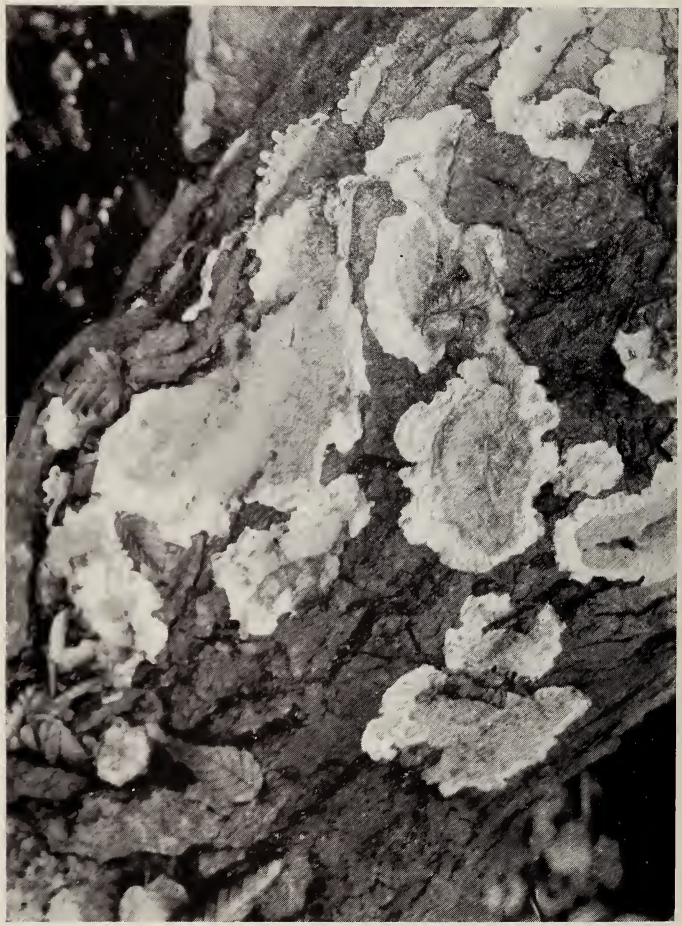

The Bright Brown Stereum Stereum couleur de Tan Kastanienbrauner Rindenfilz $\times \frac{1}{2}$ 


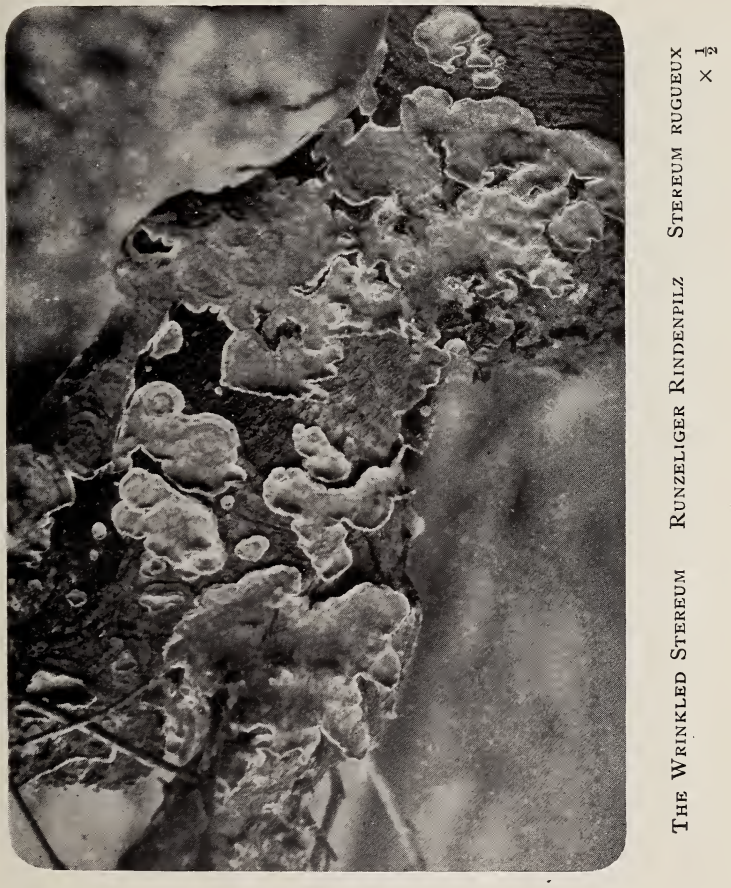


THELEPHORA CRISTATA

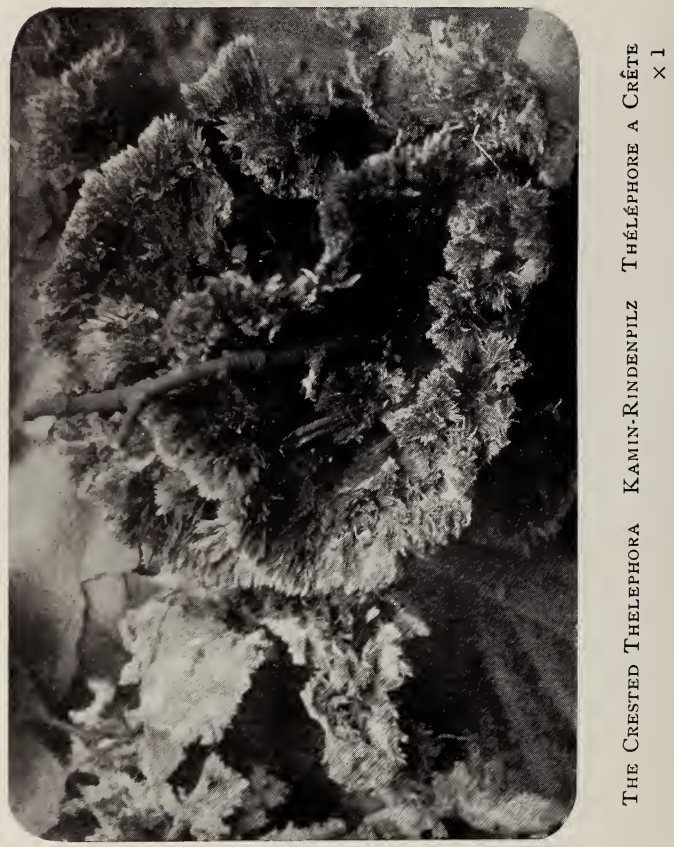




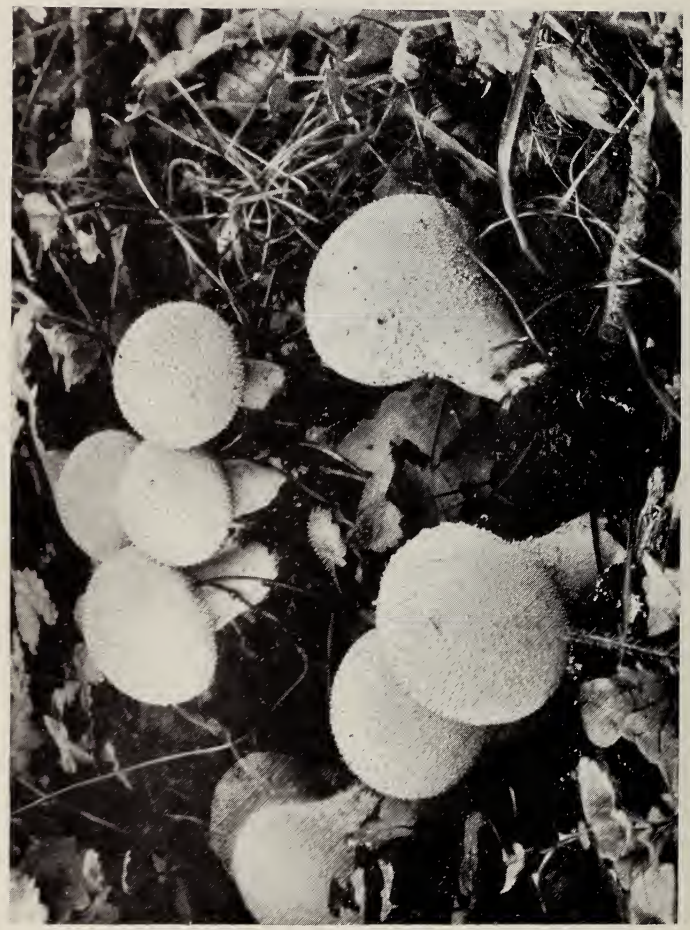

(1)

录

哇

立 


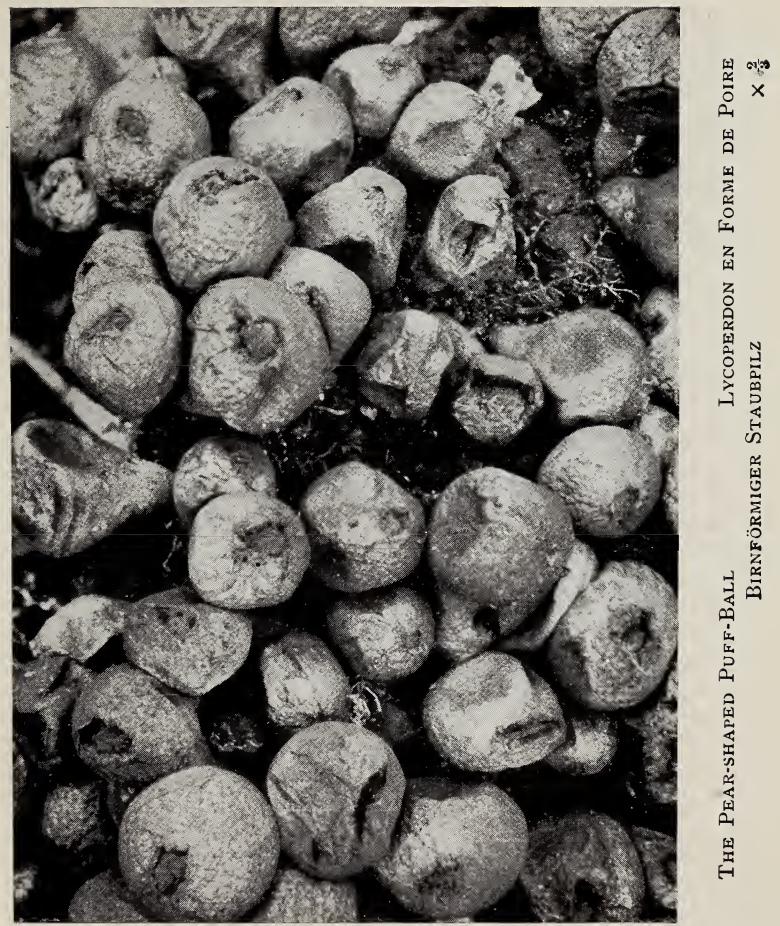




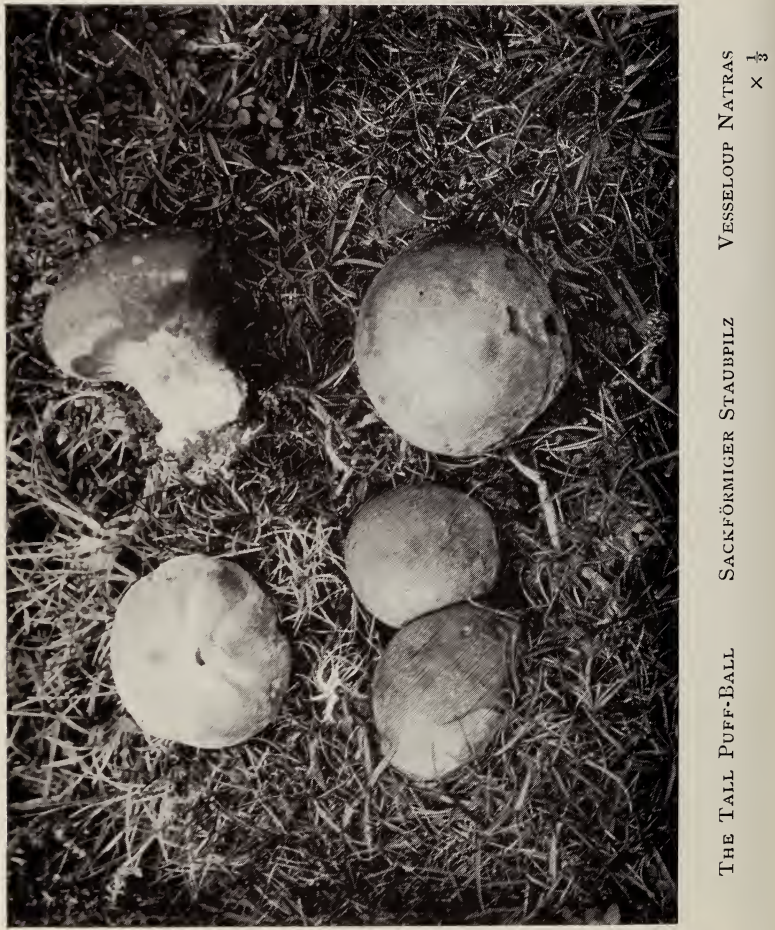




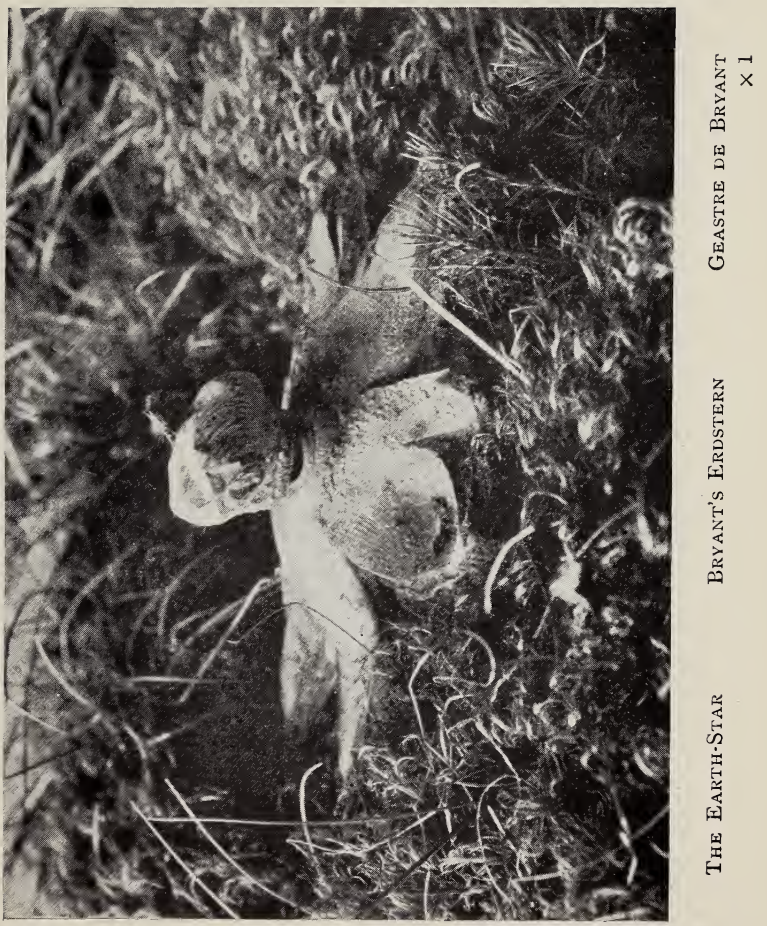




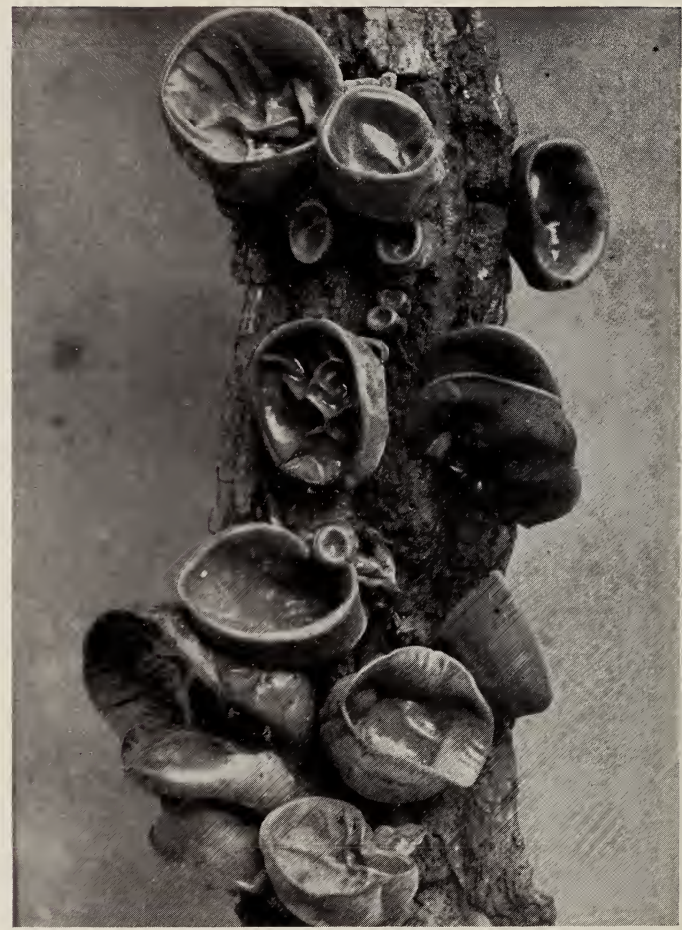

THE Jew's EAR

JUDASOHR

Oreille de Judas $\times \frac{1}{2}$ 


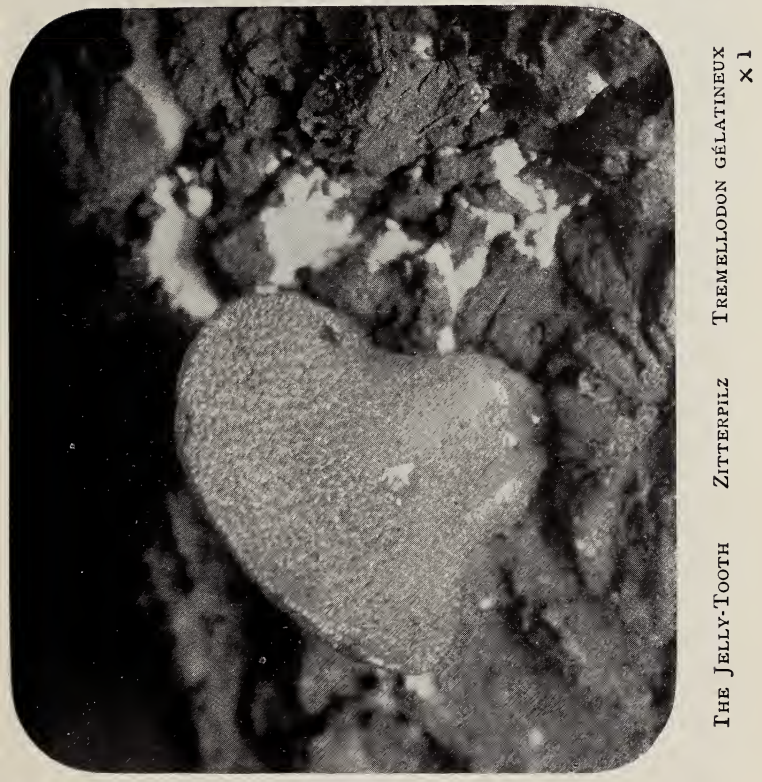




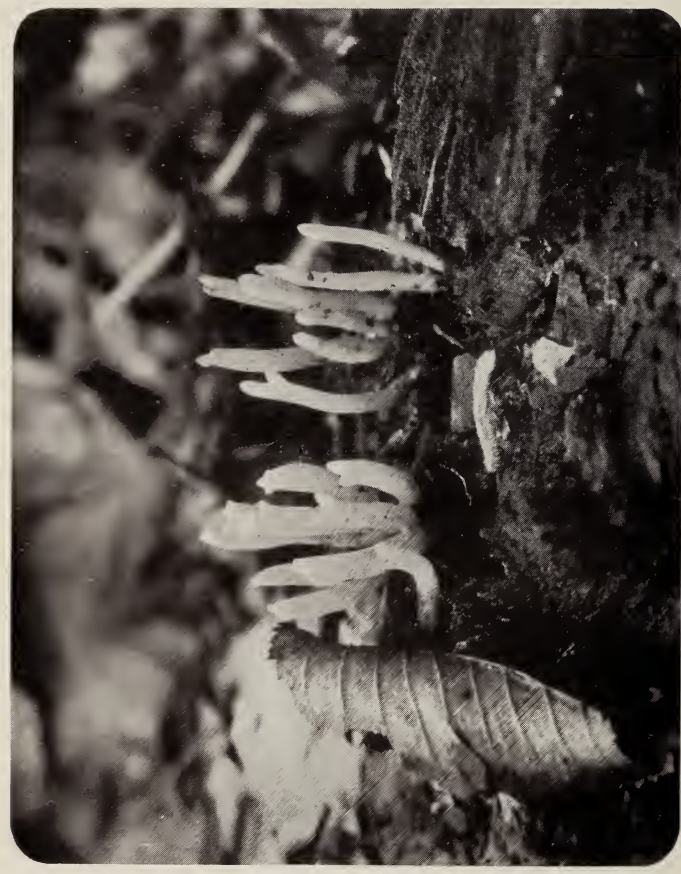

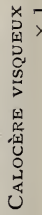

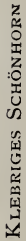

窇 


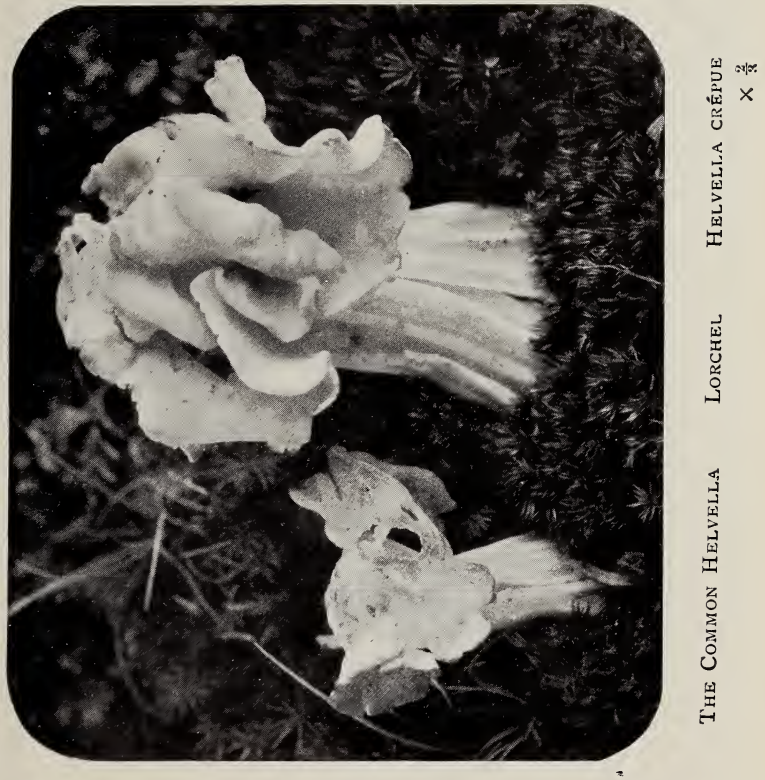




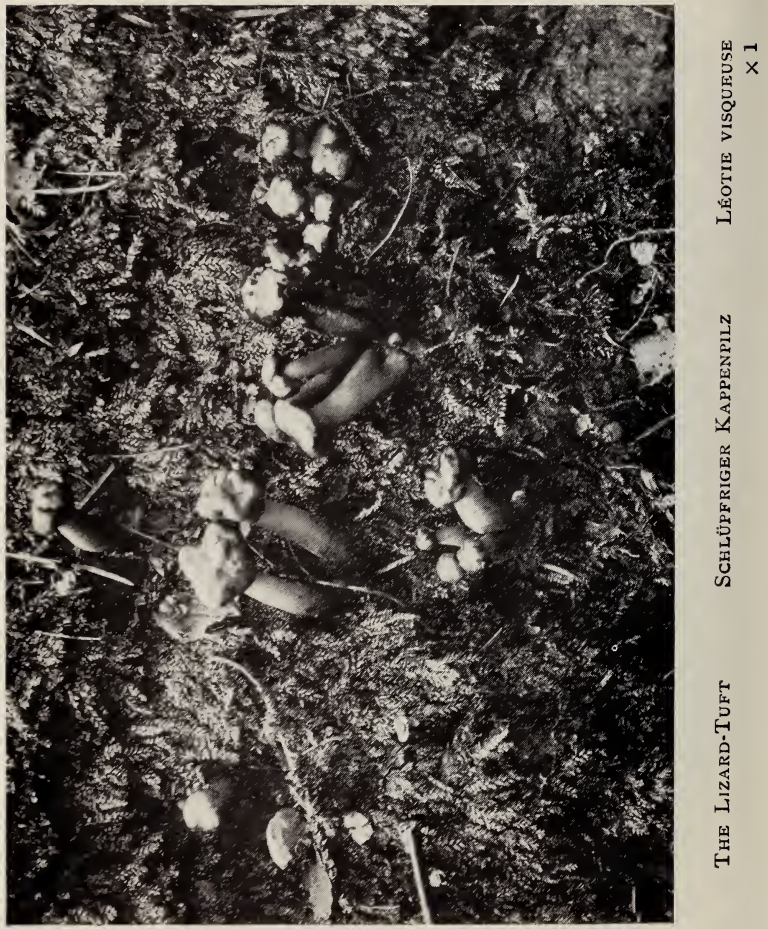




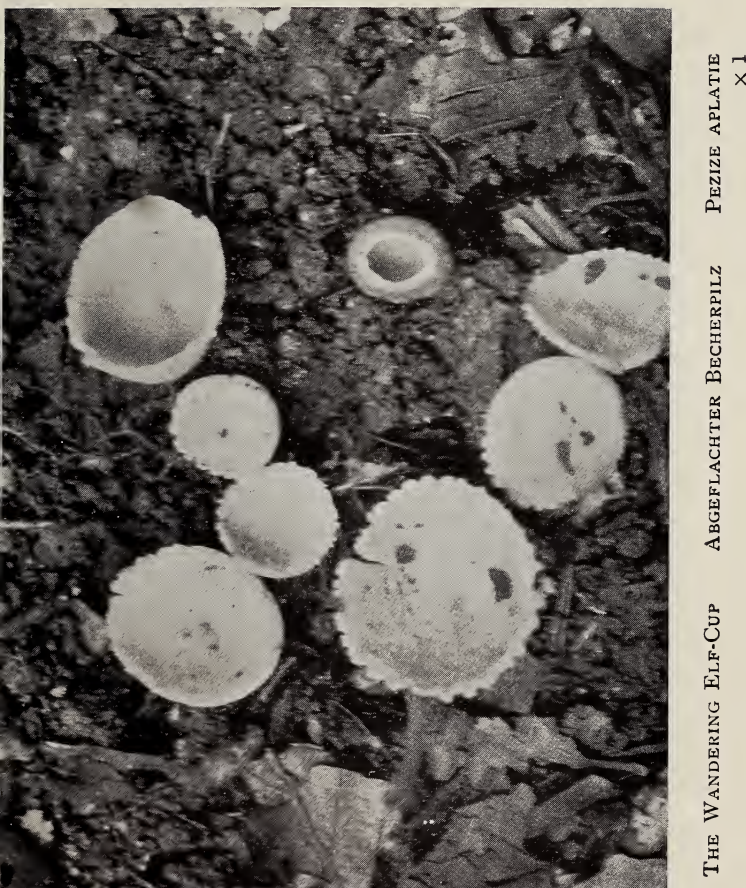




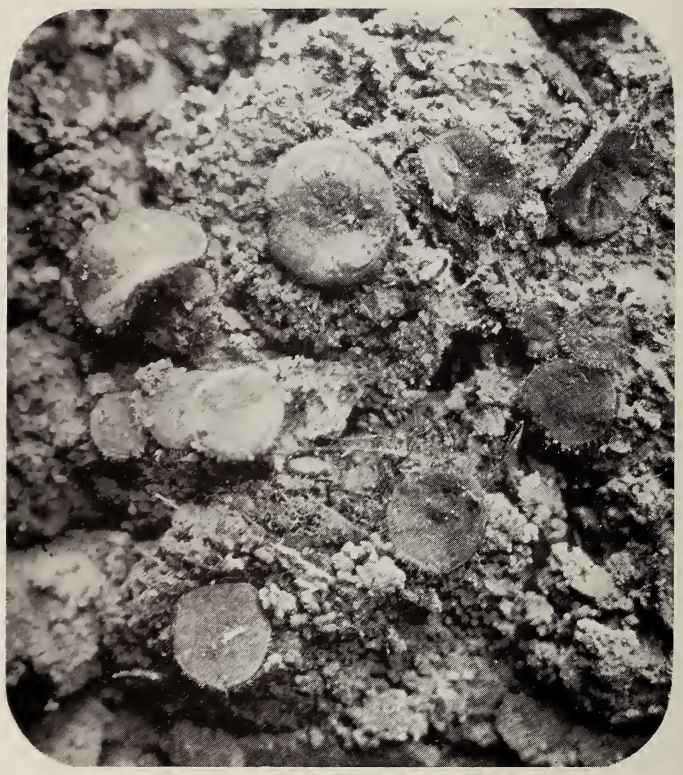

The Shield Peziza

Pezize en Bouclier

SCHILDFÖRMIGER BECHERPILZ

$\times 2$ 


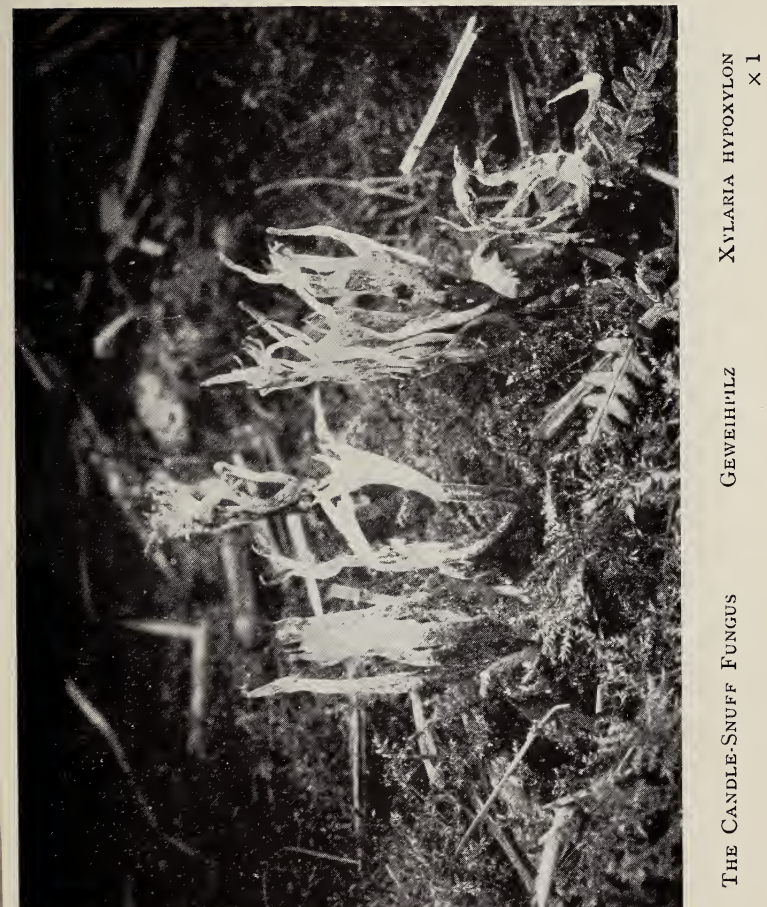




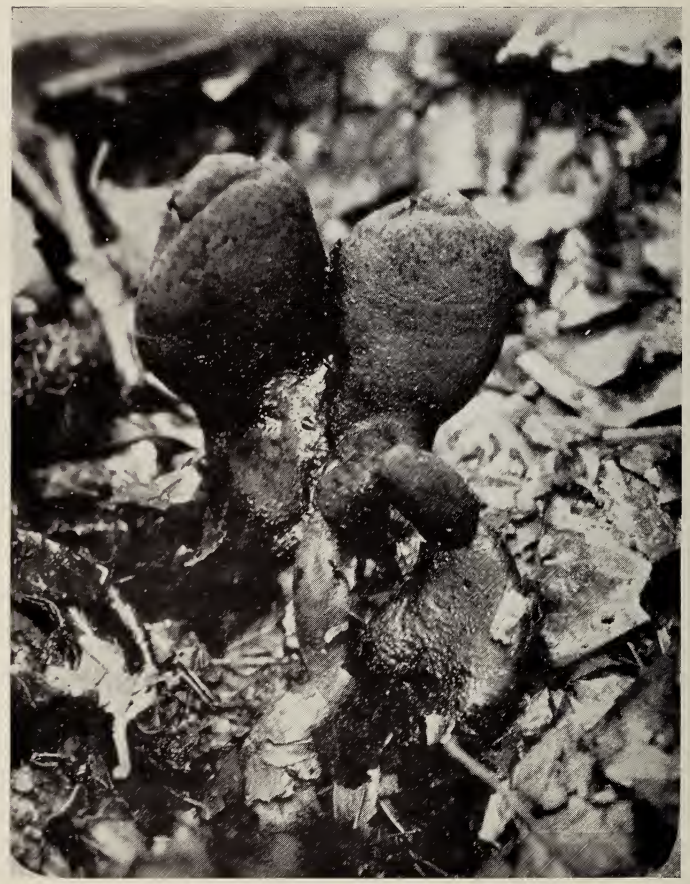

The Devil's Fingers

XYLARIA POLYMORPHE

Vielgestaltiger Geweihpilz

$\times 1$ 


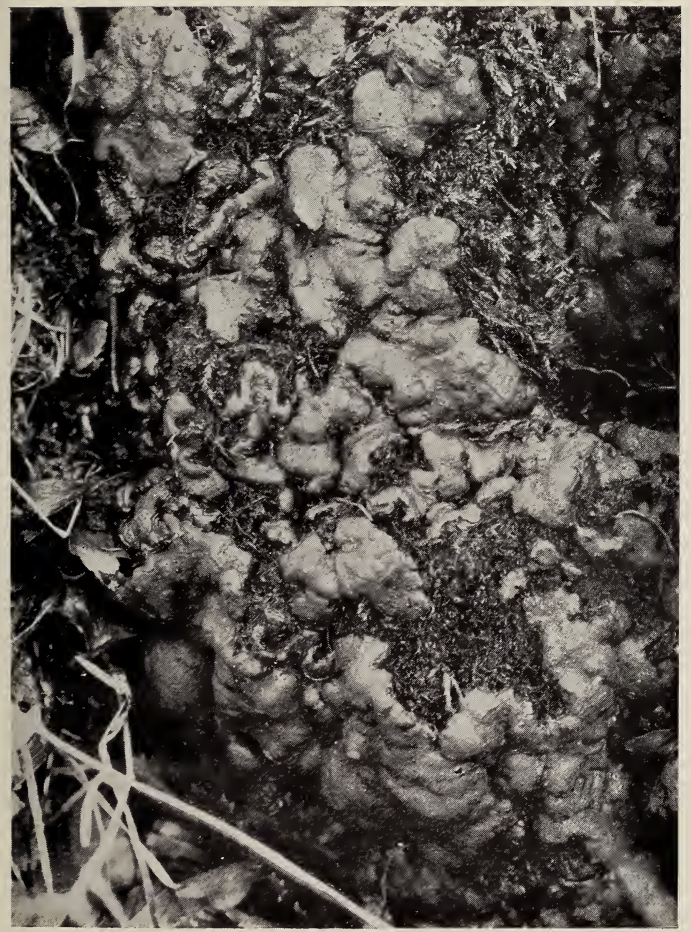

将

嚊

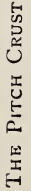




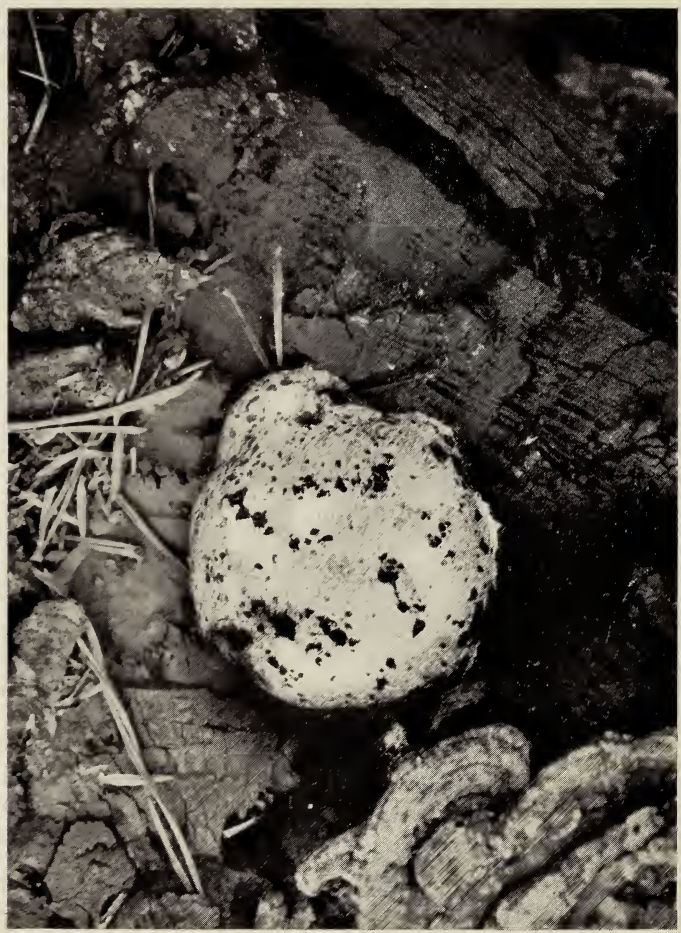

号

望

 
TOADSTOOLS AT HOME-SECOND SERIES.

\section{SOME}

\section{Notes on the Toadstools OF wHICH}

\section{PHOTOGRAPHS APPEAR IN} THE FOREGOING PAGES . •

\section{BY SOMERVILLE HASTINGS.}

One of the earliest steps in becoming familiar with the Fungi is to learn how to find out their names. It has been suggested, therefore, that perhaps some simple outline of the classification of the Fungi might be found acceptable in this series. In such a classification only the larger species will be considered, anci for the most part only those classes which are represented in this and the preceding series will be included. Strict scientific accuracy will in some cases have to be sacrificed for the sake of simplicity.

Suppose then we meet with one of the larger Fungi, we may make use of the following table to determine to which of the main classes it belongs:-
A. Whole Fungus under ground. Truffles (Tuberaceae),
B. Most of Fungus above ground. 
a. Whole Fungus gelatinous, slimy (but may be horny when dry).

Tremellas (Tremellinae), and Jew's Ears (Auriculariae).

Fungi in form of an umbrella or shelf, with gills below. The Toadstools proper (Agaricineae).

Fungi in form of an umbrella or shelf, with pores below, or of a flat surface with pores above. Pore-toadstools (Polyporeae).

Fungi in form of an umbrella or shelf, with spines below. Spine-toadstools (Hydneae).

Fungi in the form of a stag's horn or little tree (Pages 50 and $5 \mathrm{I}$, First Series), which may be unbranched, or in the form of a sponge without a stalk (Page 49). Stag's Horn Fungi (Clavarieae).

Fungi of sponge-like texture, with the remains of the sheath in which they were at first enclosed at the bases (Pages 52 and 54, First Series). The Stink-Horns (Phalloideae).

More or less spherical forms, when mature consisting of a bag with or without a pore, full of powdery spores (Page 55, First Series). The Puff-Balls (Lycoperdeae).

Small Fungi in the form of a bird's nest containing egg-like inasses of spores (Page 54, First Series). Bird's-Nest Fungi (Nidularieae).

Dark slow-growing forms of solid woody texture which do not easily decay, usually on trees and stumps. The CandleSnuff Fungi (Pyrenomycetes).

Fungi in the form of a cup (Page 59), or of an irregular mass borne on a stalk (Pages 57 and ${ }^{8} 8$ ). Cup-fungi and Morels (Discomycetes).

Fungi in the form of a hollow cone (Page 49, First Series), or of flattened or irregular leathery masses usually growing on trees and stumps (Pages 44 to 48 ). The Thelephores (Thelephoreae).

The above classification, though quite unscientific, may assist the reader in deciding to which of the main classes a given Fungus belongs. The last two classes will be found especially difficult to distinguish from one another, and here it may be said generally that where difficulty arises in deciding to which of two classes a Fungus belongs, it is well to work along both the lines indicated until some definite evidence of the plant's true nature is forthcoming.

Before taking up the sub-divisions of the main classes above indicated, a few notes on the more scientific classification of the larger Fungi may not be entirely out of place.

The larger Fungi or Eumycetes as they are called, are divided into two main classes (the Ascomycetes and Basidiomycetes) by the method in which their spores are produced. In the Ascomycetes four to eight spores are produced within each bag or cell called an Ascus. In the Basidiomycetes the spores are budded off on the outside of cells called Basidia. In the Ascomycetes it has been shown that the formation of the Ascus is in, at any rate, some cases preceded by cell fusion, which is to be regarded as a true sexual process. In the Basidiomycetes nothing of this kind has been observed. Of the sub-divisions of the Ascomycetes three only are here mentioned. The Discomycetes which hear Asci full of spores all 
over their free surfaces, the Tuberaceae which are underground forms having their Asci only within, and the Pyrenomycetes with groups of Asci contained in little pits. The greater number of the Basidiomycetes bear four spores at the extremity of each of their basidia. In the Thelephoreae, Clavarieae, Hydenae, Polyporeae, and Agaricineae, classed together as Hymenomycetes, the basidia are found on the free surface, but in the Gasteromycetes, which include the Phalloideae, Nidularieae and Lycoperdeae, the basidia are within. The Auricularieae have basidia which are transversely divided, while in the Tremellineae the divisions are longitudinal.

The principal sub-divisions of the above main classes will now be considered, and the indications given for the recognition of the principal genera. It will be remembered that a genus is a class, while a species is the name of an individual. The genus Agaricus is very large and is sub-divided into many sub-genera.

The Truffles (Tuberaceae) form firm egg-like masses, usually of a dark colour, found beneath the soil, particularly in woods. Most Truffles have an aromatic smell and taste, and several species are used as flavouring agents. They are searched for by the aid of pigs and dogs which detect them by their odour beneath the soil. Most of the edible varieties come from France and Italy.

Apart from the manner in which their spores are borne, which is only to be determined with the microscope, the gelatinous character of the Tremellas (Tremellaceae) is their most characteristic feature. Some of the Cup Fungi (Discomycetes), notably Bulgaria (Page 63, First Series), are also gelatinous, but the regular cup-like shape of the fructifications of these latter will prevent any error occurring. Of the Tremellas, Tremellodon (Page 55), is recognised by the tooth. like projections on its lower surface. Calocera (Page 56), is of a hranched form like a little tree, and may easily be mistaken for a Stag's-horn Fungus (Clavaria) unless its gelatinous character be very' carefully noted. Tremella or Coryne (Page 59, First Series), takes the form of a soft flattened or irregular mass often brightly coloured. Phlebia vaga (Page 43), one of the Hydneae, might very easily be mistaken for a Tremella.

The Jew's Ears (Auricularieae) are also gelatinous. The common Jew's Ear (Auricularia sambucinia, Page 54) is of a dark brown colour and of an irregular cup-like shape, veined and folded within. It is very common on the bark of old elder trees, and is occasionally seen on elms. It becomes shrivelled up, hard and dry when the weather is fine, reviving again completely when it rains.

The Toadstools Proper (Agaricinae) form a very large class. They are usually classified according to the colour of their spores, which is generally similar to that of the gills on which they are borne, but not invariably so. Accordingly, to determine accurately the colour of the spores, it will be necessary to break off the stalk from a mature specimen, and leave the toadstool cap gills downward on a piece of white or printed paper for at least 12 hours. In most cases the colour of the spores may be taken as similar to that of the gills of a mature species, but a few toadstools with coloured gills bear white spores. 
Another important point in the classification of the toadstools proper is the way in which the gills are attached to the stem. The following diagram, showing the four principal methods, will serve to make this clear.

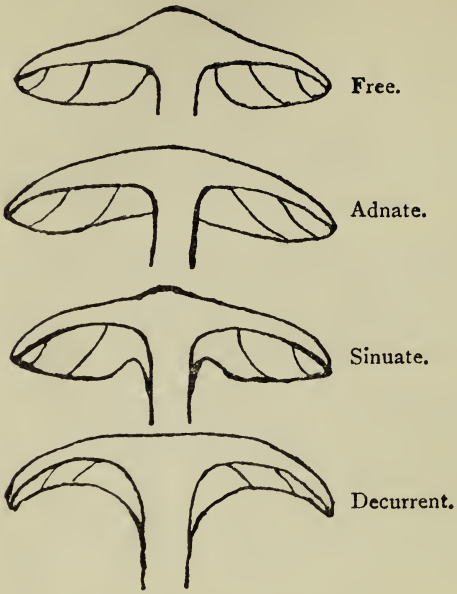

1. SPORES WHITE OR NEARLY SO.

(A) Toadstool Fleshy and Putrescent, not Leatiery.

(a) Gills free, not attached to stem. (See diagram).

Warts on cap easily picked off, base of stem often enclosed in sheath. Agaricus [Amanita], (Frontispiece).

Scaly warts firmly fixed to cap, no sheath at base of stem. Agaricus [Lepiota], (Page 12, First Series).

(b) Gills united with stem.

(i) Shelf-like forms without central stem. Agaricus [Pleurotus], (Page 22, First Series).

(ii) Stem central.

I. Stem with Thickened Cartilaginous Exterior.

Gills adnate (see diagram). Toadstool fleshy. Agaricus [Collybia], (Page ro).

Gills sinuate (see diagram). Toadstool usually small, with thin soft cap. Agaricus [Mycena], (Page II). 
II. Stem without Thickened Exterior.

(a) Stem with ring. Agaricus [Armillaria], (Pages 13 to 15, First Series).

(b) Stem without ring.

Gills Sinuate (sce diagram).

Cap fleshy, stem short. Agaricus [Tricholoma], (Page 6).

Gills Decurrent (see diagram).

Gills with thickened margin branched and coloured. (Cantharellus, Pages 25 and 26).

Gill margins thin, Toadstool waxy and bright coloured, growing on ground. Hygrophorus (Pages 2I and 22).

Gills thin, stem fibrous. Agaricus [Clitocybe], (Pages 7 to 9 ).

Gills thin, mealy coloured. Agaricus [Laccaria], (Page I2).

Toadstool exuding milky juice when injured. Lactarius, (Pages 19 and 20 ).

Gills Adnate (sec diagram).

Toadstool dry and brittle. Russula (Pages 16 to 18 ).

Toadstool waxy. Hygrophorus (Pages 2I and 22).

Toadstool exuding milky juice when injured. Lactarius, (Pages 19 and 20 ).

(B) Toadstools Hard and Leathery, dRying up in Fine WEATHER, TO REVIVE AGAIN WHEN WET.

(a) With central stem. Marasmius. Toadstool hard and leathery, drying up in fine weather to revive again when wet. (Pages $4 \mathrm{I}$ and 42 , First Series).

(b) Shelf-like form.

Gills unbranched. Panus (Page 27).

Gills branching. Lenzites (Pages 28 and 29).

\section{II.-SPORES ROSY OR PINK.}

There are no photographs illustrating this class.

\section{III.-SPORES REDDISH BROWN.}

(A) Stem central. Stem with well-marked ring, cap scaly, Agaricus [Pholiota], (Page $\times_{3}$ ).

Filamentus web-like veil, the remains of which may persist as a ring. Cortinarius (Pages 30 and 31 ).

Stem without ring. Margins of cap persistently rolled inward. Paxillus (Page 34, First Series).

(B) Stem lateral. Shelf-like forms. Agaricus [Crepidotus], (Page 24, First Series).

IV.-SPORES PURPLE OR PURPLE BROWN.

(A) Gills free from stem, well marked veil and persistent ring. Agaricus [Psalliota], (Pages 25 and 26, First Series).

(B) Gills attached to stem.

(i) Stem with persistent ring. Agaricus [Stropharia],

(Page 27, First Series).

(ii) Stern without ring or with fragments only.

Veil entirely absent, stem tough. Agaricus [Psilocybe], (Pages 30 and 31, First Series).

Remains of veil attached to margin of cap. Agaricus [Hypholoma] (Pages 28 and 29, First Series). 


\section{V. - SPORES BLACK.}

Gills dissolving into milky fluid. Coprinus (Pages 32 to 34 ).

Gills decurrent. Cap with radial markings. Agaricus [P sathyrella], (Page $\mathrm{I}_{5}$ ).

The Pore-toadstools (Polyporeae) form a large class, several of which are here illustrated :-

(A) With central stalk.

Fleshy forms, tubes easily separated from cap. Boletus (Pages 35 and 36 ).

Woody forms, tubes firmly fixed to cap. Polyporus (Pagres 37 and 38 ).

(B) Fungus forming shelf.

(a) Fungus fleshy.

Tubes very shallow, Fungus waxy. Merulius (Page 4r).

Tubes long, Fungus large and juicy. Fistulina (Page 43, First Series).

(b) Fungus dry, woody.

Tubes forming a definite layer all of same depth. Poly. porus (Pages 37 and 38 ).

Tubes not forming a definite layer and of different depths, corky. Trametes (Page ${ }_{4} 0$ ).

(C) Fungus forming crust, with pores above.

Pores small, deep. Poria (Page 39).

Pores large, shallow. Merulius (Page 43).

Many of the Spine Toadstools (Hydneae) have well marked spines on their lower surfaces on which the spores are borne (Page 42). Some like Phlebia vaga (Page 43) form flattened plaques with crest-like wrinkles and veins. Iremellodon (Page 55) closely resembles a Hydnum but is gelatinous.

The Stag's Horn Fungi (Clavariae) contain the genera Sparassis (Page 49) and Clavaria (Pages 50 and $5 \mathrm{I}$, First Series). sparassis is a much branched sponge-like form without a stalk which grows to a large size.

The Stinkhorns (Phalloideae) are a most peculiar group of Fungi (Pages 52 and 54. First Series). Mutinus is distinguished from Phallus by its smaller size and the absence of the belmet at the end of the spongy stem.

The Puff-balls (I,ycoperdeae) are filled with powdery spores when ripe.

(A) No pore formed. Thick outer layer which slowly decays. Scleroderma (Page 56, First Series).

(B) Pore formed through which spores are distributed. Covering of one layer only. Lycoperdon (Pages 5o to 52). Covering of two layers, the outer of which turns back in the form of a star. Geaster (Page 57, First Series).

Crucibulum is the sole representative of the Bird's-nest Fungi (Nidularieae) here illustrated (Page 58 , First Series). 
The Thelephoras (Thelephoreae) contain a good many dissimilar forms :-

Fungus funnel-shaped and large. Craterellus (Page 49, First Series).

Fungus dry and fibrous, finely divided. Telephora (Page 48).

Fungus as flat plaques on trees, not fleshy. The free surface always smooth. Stereum (Pages 44-47).

The Discomycetes also consist of a number of genera of very different external form.

(A) Fungus with a stalk which supports

A sponge like mass. Morchelia (Page 60, First Series).

A smooth viscid ovid mass, small Fungi. Leotia (Page 58).

A sort of cloak hanging down in folds. Heivella (Page 37).

(B) Fungus without stalk.

In form of a cup, fleshy. Peziza (Pages 59 and 60).

At first a cup, later changing to a flat surface. Gelatinous. Bulgaria (Page 63, First Series).

All the Pyrenomycetes here illustrated are dark and unattractive looking. A careful examination of a mature specimen will show small cavities near the surface opening externally by a pore. In these the black spores are produced.

Fungus in form of post of slightly branched tree. Xylaria (Pages 6r and 62).

Fungus in form of nearly spherical mass. Daldinia (Page 6r, First Series).

Fungus as flattened plaque covering the surface of a stump. Ustulina (Page 63).

The Scarlet Fly-Cap (Agaricus [Amanita] muscarius, Frontispiece) is one of the best known of the toadstool family. Its brilliant scarlet cap, spotted over with white warts, makes it so conspicuous and beautiful an object that even the most indifferent can hardly fail to notice it. The warts are the remains of the membranous bag in which the whole Fungus was enclosed when young. They are of moderate size and can be easily removed from the crimson cap. Rarely only one or two very large warts are present. The cap where uncovered by warts is rather sticky, and occasionally its bright crimson colour is replaced by a dull orange yellow. There is a well-marked ring. This toadstool is fairly common in woodland glades in early autumn, and is usually found in the neighbourhood of firs or birches, more especially the latter. Though so beautiful, it is extremely deadly, and many cases of poisoning in those who have eaten it are recorded. The early symptoms of poisoning and those produced by small doses are delirium and intoxication, and it has even been stated that the Fungus is made use of in some parts of the world to produce this effect. The poisonous principle is easily dissolved out so that a decoction can be readily made and is sometimes used for killing flies. It was with this Fungus that Agrippina, the mother of Nero, is supposed to have poisoned the Emperor Claudius, either intentionally or by accident, for the Scarlet Fly-Cap closely resembles the Blusher (Page 6, First Series), which was much used 
as food in Roman times. The cap of the Blusher is always of a much duller red, its warts are smaller, more scaly, and more adherent, and its flesh slowly turns pinkish when cut or bruised.

The Wood Blewit (Agaricus [Tricholoma] nudus, Page 6), is a very beautiful Fungus. It is at first of a uniform pale violet colour, but develops a brownish tint with age. The cap is silky with its margin rolled inward. It grows among dead leaves and is fairly common. Although the gills are violet the spores are white. It is edible, but rather lacking in flavour.

The Cream Clot (Agaricus [Clitocybe] dealbatus, Page 7), is a small white form with crowded gills. 'The cap is concave upward and wavy when mature. The whole Fungus is white, dry, and shining. It is fairly common among the grass in sunny places, and sometimes comes up in old mushroom beds when not wanted.

The Trumpet Clitocybe (Agaricus [Clitocybe] tuba, Page 8), resembles the last but is much larger The cap is deeply concave, indeed quite funnel-shaped. The gills run a long way down the stem. It grows in woods.

The Winter Clitocybe (Agaricus [Clitocybe] brumalis, Page 9), is a small grey toadstool, often found growing among the heather in November and December. The cap is very thin and the stem rather long.

The Spotted Collybia (Ag. [Collybia] maculatus, Page ro), is common in woods. It is of a good size. The stem is very firm with a cartilaginous bark and the gills crowded. The whole Fungus is of a cream colour spotted over with reddish brown. It has a pleasant aromatic odour. An atypical form of this toadstuol where the gills are branched irregularly to form a sponge-like mass is sometimes seen.

The Little Cap (Agaricus [Mycena] galericulatus, Page II), is a small toadstool which forms densely clustered tufts on trees and stumps. The cap is conical at first and of a pallid grey colour. It has well-marked striations except at the centre. The gills are white or pinkish.

The Violet Cap (Agaricus [Laccaria] laccata, Page 12), is an exceedingly beautiful form. The whole toadstool is of a clear violet, or rich purple, or red-brown colour. The gills are well separated from one another, and the whole cap, and especially the gills, have a mealy appearance in dry weather. The stem is long and of the same colour as the cap, and has a fibrous or silky look. This toadstool is very variable in size and grows among dead leaves in woods.

The Tawny-Tuft (Agaricus [Pholiota] spectabilis Page $\mathrm{r}_{3}$ ), is a fair-sized toadstool which grows in clumps on old trees. The cap is of a tawny yellow colour covered with silky scales. The gills are brownish yellow. It closely resembles the Prickly Cap (Ag.[Pholiota] squarrosus) shown on Page 23 of the Firvt Series, but the scales on the cap are more silky and less prominent. It has a faint but unpleasant smell. 
The Dung Stropharia (Ag. [Stropharia] merdaria, Page 14), is a small toadstool which grows on dry dung. The cap is viscid and of a yellowish brown colour. The gills are greyish yellow and the stem fibrous. There is usually the remains of a ring round the upper part of the stem.

The Tufted Psathyrella (Ag. [Psathyrella] disseminatus, Page 15), grows in dense tufts on old stumps. It has black spores. The cap is greyish yellow, striated round the margin and covered with scattered scaly particles. The gills are at first grey and later black. It is a fragile little plant.

The Black Russule (Russula nigricans, Page 16 ), is a large coarse toadstool which grows in woods. It is white or greyish at first but turns reddish when bruised. As it gets older it becomes blackish. The gills, also, white at first, are widely separated from one another.

The Scorched Russule (Russula adusta, Page 17 ), also grows in woods. It is at first white but soon becomes spotted with sootygrey stains as if it had been scorched. It is not unlike the Black Russula above described, but differs from it in being smaller, drier and less juicy, and in never changing to a reddish tint when bruised. The gills too are much more crowded together.

The Brazen-faced Russule (Russula ochroleuca, Page 18 ), is a fair-sized toadstool which grows in woods. It has a dingy yellow cap, broad white gills very evenly arranged, and a greyish white stem. Its taste is acrid and it is believed to be poisonous.

The Dirty Lactar (Lactarius turpis, Page 19), is a large toadstool yielding a white milk when injured or broken. The cap is covered with a dark olive slime. The gills are very crowded, pale pink or straw coloured, and spotted with brown where injured. The stem is stout and short and of an olive colour. It is distinguished from the Slimy Lactar (Lactarius blennius, Page 37, First Series), which closely resembles it by the darker colour and downy incurved margin of the cap of the Slimy Lactar.

The Woolly White Lactar (Lactarius vellereus, Page 20), also exudes a milky juice when cut or injured, but this is usually very small in quantity. It is a large toadstool with a pure white cap, which generally becomes almost cup-shaped when mature. The cap is somewhat woolly but is never flesh coloured like the cap of the Woolly Milk Mushroom (Lactarius torminosus) shown on Page ${ }^{6}$ of the First Series.

The Parrot Hygrophorus (Hygrophorus psittacinus, Page 2r), is a small Fungus which grows in fields. The cap is covered by a brilliant green slime, and as this gets washed off and exposes the yellow or orange colour of the rest of the toadstool, most brilliant effects are produced.

The Melon Hygrophorus (Hygrophorus pratensis, Page 22), is a very beautiful form which grows in meadows and woods. It is of a beautiful orange colour and has often a melon-like smell. The gills are widely separated. 
The Snowdrop Hygrophorus (Hygrophorus nivens, Page 23), is a pretty little Fungus which often comes up on lawns. It is pure white with delicate membranous gills. It is much smaller and more delicate than the somewhat similar species shown on Pages 8 and 9.

The True Chantarelle (Cantharellus cibarius, Page 24), is known by its somewhat irregular form and the uniform deep yellow colour of the whole fungus. The gills take the form of branched veins, ard the whole plant, after being kept a few hours, develops a pleasant apricot smell. It is fairly abundant in woods, especially in those of beech. The Chantarelle is one of the nicest of the edible fungi, but being rather tough requires prolonged cooking. It is best when stewed for several hours.

The False Chantarelle (Cantharellus aurantiacus, Page 2g), is distinguished from the true Chantarelle by the thinner and more membranous gills, which are of a deeper yellow colour than those of the true, while the cap is much paler. It grows in fir woods and among bracken, and is said to be poisonous. There is no doubt, however, that it has frequeutly been eaten without ill effect.

The Funnel Chantarelle (Cantharellus tubæformis, Page 26), is common in woods. The cap is brownish-yellow, and the widely separated gills are yellow-grey, and frosted with a whitish bloom. The stem is tawny orange.

The Styptic Sprout (Panus stypticus, Page 27), is a small yellowish-brown fungus, which grows in clusters on trees and stumps. It is usually without any stalk. It dries up in fine weather, and revives again when moist. Its pungent peppery taste is most distinctive.

The Birch Lenzites (Lenzites betulina, Page 28), and the Flaccid Lenzites(Lenzites flaccida,Page 29), are dry woody forms, with irregular gills, and without stalks. They very closely resemble one another. The cap of Lenzites flaccida is thinuer and more easily bent, and the gills are thicker and branch only at the base. In spite of the name, Lenzites betulina is sometimes found on other stumps besides those of birch. The velvety caps of both species are olive-brown, and the gills white.

It has already been mentioned that the Genus Cortinarius is distinguished by its filamentous or spider's-web-like veil. The Saturnine Cortinarius (Cortinarius saturninus, Page 30 ) is a good-sized toadstool, with a reddish-brown cap. It grows among long grass. The Silvery Cortınarius (Cortinarius argentatus) is seen on Page 3I. It is a large toadstool, with a strong and rather unpleasant smell, and grows in woods. The cap is dry and silky, and of a silvery-grey colour, often with a tinge of lilac. The gills are brownish.

On Pages 32, 33, and 34 are three photographs of Shaggy-Caps (Coprinus comatus). Almost as soon as the toadstool is fully expanded (Page 33), it begins to dissolve into an ink-like fluid, and a few hours later nothing but the naked stalks smeared over with a sticky black material are to be seen. Shaggy-Caps is the commonest toadstool in the neighbourhood of human habitations. On rubbish 
heaps of all kinds. and made soil, it is found abundantly from early sunmer right on till late autumn. It is edible, and one of the best of the toadstools; perhaps even nicer than the common mushroom, which it closely resembles in flavour.

The Edible Boletus (Boletus edulis) is photographed on Page 35 . It is one of those Boleti whose flesh does not change in colour when broken or cut. It is a large fleshy form. Its cap is brown and inclined to be slimy; its gills greenish-yellow, and its stem buff, with not very distinct blackish markings. The Summer Boletus (Boletus aestivalis, Page 43, First Series) is distinguished from the above by the lighter colour and more silky character of its cap and the absence of markings on its stem. The Edible Boletus is common in woods in early autumn, and is largely eaten on the Continent. When cooked alone it tends to be gelatinous and tasteless.

The Yellow Boletus (Boletus flavus, Page 36 ), is a very characteristic fungus. The whole plant is of a bright-yellow colour, the gills being, as a rule, a little darker than the cap and stem. The cap is slimy above. The stem has a few black markings near the top, and is surrounded by the remains of a brownish ring. The flesh is pale yellow, and does not change colour when broken or cut.

The Large Pine Polyporus (Polyporus Schweintzii, Page 37), is a large brown fungus, with a short central stalk. It is common in pine woods, growing around the roots and stumps, and often attains a very large size. As the fungus grows it tends to envelop anything that may be near, and thus are found twigs, grass, and pine needles embedded in it.

The Varnished Polyporus (Polyporus lucidus, Page ${ }^{8} 8$ ), is a very curious form. The pores are white and very minute, and both the cap and elongated stem are of a dark, reddish-brown colour, with a shiny polished appearance, looking exactly as if they had been lacquered or varnished. The fungus grows on roots and stumps, is dry and woody, and so resistant of decay that it has been found preserved in peat-beds and around the ancient pile-dwellings of Switzerland.

The Manna of the Woods (Poria hibernica, Page 39), is met with as whitish spots, which appear on pine wood, and soon run together to form a thin layer, with a granular appearance not unlike snow. The granular appearance is caused by the rather irregular pores in which the spores are borne.

The Genus Trametes may be considered as a connecting link between the gill-toadstools (e.g. Lenzites, Pages 28 and 2.9) on the one hand and the pore-toadstools (such as Polyporus, Pages 27 and 28 ) on the other, for in it the pores are radially elongated. The Sweet Trametes (Trametes suaveolens, Page 40), generally grows on the trunks of willows. Its cap is greyish, and its elongated pores, which are at first whitish, later acquire a tinge of red. When young it smells like aniseed. 
The best-known member of the Genus Merulius is the Dry-Rot fungus (Merulius lacrymans). The Jelly-Rot (Merulius molluscus, Page $4 \mathrm{I}$ ), is a soft, almost gelatinous fungus, which grows on decaying wood. Its pores are much more irregular and shallower than those of Poria and Trametes, and it is of a much softer consistency.

The Urchin of the Woods (Hydnum repandum, Page 42) is fairly common in woods, and will be easily recognised from the photograph. Its colour is white or cream. The cap is usually turned up at its edges, and is somewhat irregular in form, the stem being often a good deal to one side. This fungus is considered a great delicacy, but is rather peppery, and requires prolonged stewing.

The Vein Crust (Phlebia vaga, Page 43 ) is an unattractive fungus of a greyish-yellow colour. It is soft and almost gelatinous, and forms flattened plaques, spreading over the surface of dead wood. The free surfaces of these plaques are wrinkled, and bear the minute spores. The genus Phlebia closely resembles Merulius, but the ridges on the surface are less definite, so that the pores between them are more irregular and shallower. It is very probable that the two genera are closely related.

We now come to the genus Stereum, of which there are four examples here illustrated. In Stereum the spore-bearing surface is flattened, and entirely without wrinkles or ridges. The fungus, which is corky or leathery, forms flattened plaques, which grow over the surface of dead wood or form shelf-like projections. The Hairy Stereum (Stereum hirsutum, Page 44 ) is common on fallen branches at almost all seasons of the year. The spore bearing surface, which is usually the lower, is of a dingy orange-yellow colour. The upper surface is clothed with stiff grey hairs, which are not infrequently greenish from the presence of minute Algae. A very fine specimen of the Purple Stereum (Stereum purpureum) is photographed on Page 45. It is only purple when quite young, and rapidly turns a whitish-grey, zoned with brown as it grows older. When dry it is firm and rigid, but when moist, though soft and flexible, it is extremely tough. The upper surface is covered by soft velvety hairs, quite different from the long stiff bristles of the Hairy Stereum (Page 44). The Bright Brown Stereum (Stereum spadiceum, Page 46 ) forms thin horny plates on the surfaces of the trunks and branches of trees. The upper spore-bearing surface is smooth and of a brownish flesh-colour, but turns bright red when bruised. This latter character, taken with its colour, will serve to distinguish it from all other species. For instance, the Wrinkled Stereum (Stereum rugorm, Page 47) also changes to reddish when cut or bruised, but its spore bearing surface is greyish-yellow. It is common on fallen branches.

The Crested Thelephora (Thelephora cristata, Page $4^{8}$ ), of a greyish colour, often tinged with purple, and grows in tufts anongst moss and dead leaves.

The Sparassis (Sparassis crispa, Page 49), forms a bright yellow fragile, sponge-like, mass, often as large as one's head. It grows amongst heather and in pine woods, and is sure to be easily recog. nised. It is excellent eating when stewed in milk. 
Three species of puff-ball are illustrated in the present Series, and one on Page 55 of the previous volume. The Pillar Puff-Ball (Lycoperdon gemmatum, Page 5o) is the common little puff-ball of downs and pastures. Its surface is at first covered with warts, which later fall away, and its base is prolonged into a thick stem, which tapers downward, and does not contain spores. If eaten it should be gathered in its young state and thoroughly cooked. Lycoperdon perlatum (Page 55, First Series) closely resembles this species, The Pear-shaped Puff-Ball (Lycoperdon pyriforme, Page 5I), grows in clusters on rotten wood. It is generally easy to trace white branching rootlets from the base of the puff-ball, which pass inward to the rotten wood on which the fungus grows. They form the mycelium or true fungus plant which absorbs nourishment from the decaying wood. When mature the spores are contained in a very thin membrane. The Tall Puff-Ball (Lycoperdon saccatum, Page 52) is usually easily recognised by the folds which are almost invariably present below. It grows to a fair size, and is found in open woods.

Another species of Earth -Star (Geaster Bryantii) is seen on Page 53. It should be compared with the photograph of Geaster seriscus, to be found on Page 57 of First Series. Geaster Bryantii grows in woods, and is at once recognised from all other species by the wellmarked ring round the puff-ball stalk.

The Jew's Ear (Hirneola Auricula-Judx or Auricularia sambucina, Page 54) has already been described.

The Jelly-Tooth (Termellodon gelatinosum, Page 55) will be recognised at once by the regularly-arranged layer of short spines and its translucent gelatinous character. It usually grows on pine stumps, but is sometimes met with growing on the ground.

The Sticky Calocera (Calocera viscosa, Page ${ }_{56} 6$ ) differs from Clavaria (Pages 50 and $5 x$, First Series) in its gelatinous character. It is of an orange-yellow colour, and one or two inches high, the specimen photographed being rather sinall. It grows on pine and fir stumps, the lower part of the fungus penetrating far into the decaying wood.

The Common Helvella (Helvella crispa, Page 57), grows on the ground in woods, but is rather rare. The fragile, almost translucent, cap is usually of a pale yellowish-brown colour, but rather variable in tint, and the stem is white. From other species of Helvella it is recognised by the stout hollow stem, broken up by ridges and furrows external'y. It is edible, but is lacking in flavour, and apt to be tough unless stewed for a long time.

The Lizard-Tuft (Leotia lubrica, Page ${ }^{8} 8$ ), grows among moss in woods. It is a small inconspicuous fungus, with a dull greeni $\mathrm{h}$ yellow cap and a white stalk. It is soft, sticky, and almost gelatinous.

The Wandering Elf-Cup (Peziza applanata, Page 59), is of a dingy greenish-grey colour, and usually grows on old rotten wood. The margins of the cap are at first thickened. 
The Shield Peziza (Peziza scutellata, Page 6o), though a very small fungus, is fairly conspicuous on account of its bright red colour. The scarlet shield-like disc is found growing on the ground and on dead wood, and is surrounded by a ring of long black hairs. It is exceedingly difficult to conceive of what advantage the bright conspicuous colour of this and so many other fungi can be to the plant.

The Candle-Snuff Fungus (Xylaria hypoxylon, Page 6r), is extremely common on stumps in early autumn. It is a dry woody form, and is repeatedly branched above. The branches are covered wiıh a sort of mildew, which is really a mass of spores, and the ground around is often white with it. The base of the stem is clothed with short black hairs, among which are little pits, from which a sticky black substance can be squeezed-another sort of spore.

The Devil's Fingers (Xylaria polymorpha, Page 62), a near relation of the Candle-snuff Fungus, bears only the last-named kind of spores, which are contained in little pits all over the surface of the fungus. It is much larger and grows in irregular club-like masses on old stumps. The clubs are at first greyish, but later become coaly black.

The Pitch Crust (Ustulina vulgaris, Page 63), is also found on stumps, where it forms a jet black incrustation, looking exactly as if tar had been spilt. The openings of the little pits which contain the spores will be easily seen. They can be made out even in the photograph.

The Fairies' Pin-Cushion (Reticularia lycoperdon, Page 64), is the largest of the Mycetozoa. A short note on the very curious group of organisms-one hardly knows whether to say animals or plants-is to be found on Page 75 of the First Series. The photograph represents the resting stage, and shows a capsule filled with exceedingly minute spores. The whole organism has changed to a mass of spores and its enclosing membrane.

\section{[17 NOV 1972}




\section{REPERTORY PLAYS}

Published under the supervision of Alfred Wareing

Parchment Cover, Price 6d. net each;

Postage ra.

I THE LAST MAN IN, a Play in One Act, by W. B. Maxwell (author of "Vivien," "The Guarded Flame," etc.).

2. THE FOUNTAIN, a Comedy in Three Acts, by George Calderon (author of "Downy V. Green at Oxford," etc.).

3. THE PRICE OF COAL, a Play in One Act, by Harold Brighouse.

4. AUGUSTUS IN SEARCH OF A FATHER, a Play in One Act, by Harold Chapin.

5. A WEAVER'S SHUTTLE, a Comedy in Three Acts, by Anthony Rowley.

6. BARBARA GROWS UP, a Comedy in Three Acts, by G. J. Hamlen.

7. THE MARRIAGE OF COLUMBINE, a Comedy in Three Acts, by Harold Chapin.

LONDON \& GLASGOW: GOWANS \& GRAY, L'T'D 


\section{NOVELTIES, :: :: CHRISTMAS, I9Io.}

r. MARY QUEEN OF SCOTS. A Poem by Henry Glassford Bell. With four photogravure illustrations after Robert Herdman, R.S.A. Paper Cover, 6d. net.

2. MASTERPIECES OF LYRICAL TR ANSLATION. Uniform with "Lyric Masterpieces by Living Authors." Parchment Cover, 6d. net.

3. LES CHEFS-D'GUUVE LYRIQUES DE VICTOR HUGO. Choisis par Auguste Dorchain. Parch. ment, 6d. net; Cloth, is. net; Leather, 2s. net.

4. TURNER'S LIBER STUDIORUM. Miniature Edition, with all the unpublished plates. Paper Is. net; Cloth, Is. 6d. net; Leather, 2s. 6d. net.

5. CLYDE SONGS AND O'THER VERSES, by J. J. B., author of “Wee Macgreegor." Cloth, 2s. 6d. net. Limited Edition on Handmade Paper, 5s, net.

6. THE GARDEN OF SHADOWS. A Novel by James MacNab, 2s. 6d. net.

Also New Volumes in other Series (See Art Books, Nature Books, etc.).

LONDON \& GLASGOW : GOWANS \& GRAY, LTD. 



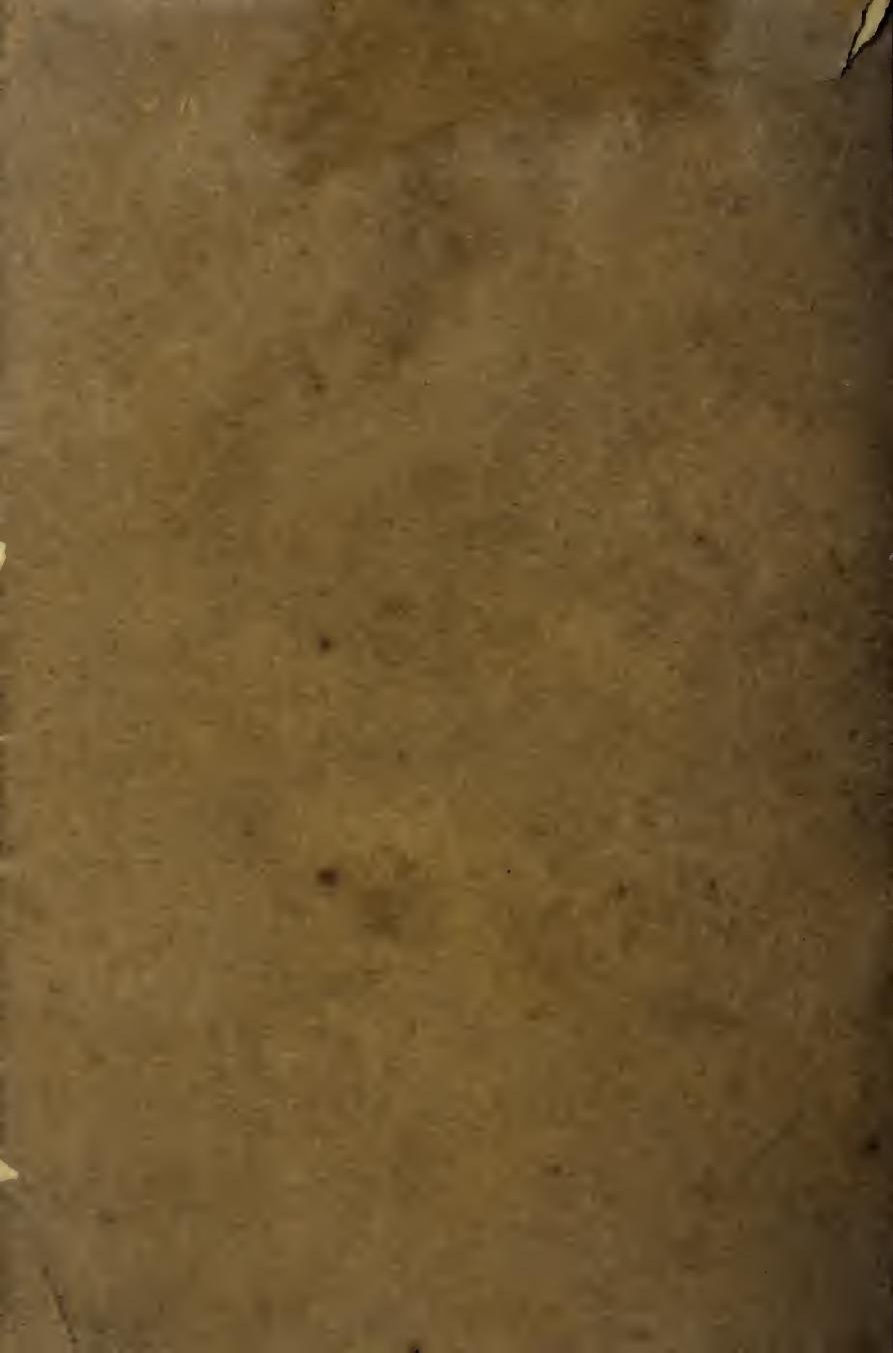

